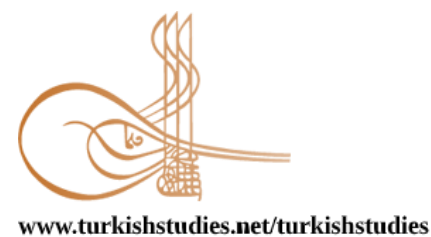

Turkish Studies

\title{
Değişen Yaşlııı Algısı: COVİD-19 ile Damgalanan Yaşlılar
}

\author{
Changing Elderliness Perception: The Elders Stigmatized By COVID-19
}

\author{
Öznur Yaşar ${ }^{*}$ - Nazmi Avcı ${ }^{* *}$
}

\begin{abstract}
The rapid spread of COVID-19 Virus and its becoming a pandemic caused the world to take serious measures. Like all over the world, various measures have been taken in this context in Turkey. One of these measures is that the elders do not go out because the information obtained so far about COVID-19 infection has shown that some people are at higher risk of getting sick and developing serious symptoms. Among these people, the people aged 65 and over are often considered to be among the groups at risk by specialists. However, with COVID-19, it is seen that the emphasis of elderliness in the society is drawn from the area 'risky for the elders' to the area 'dangerous elders'. Especially with the curfew imposed on people over 65 years old after the epidemic, the elders started to face disrespectful behaviours and even bullying in social media and in everyday life. This situation is an indicator of various losses in their status and roles. Respecting and valuing the elders is one of our important social characteristics. Respecting the elders is present in the family life and tradition of the Turkish society because they are the most important link between past and future. In this study, how the elders are included in the newspaper news with the ban over the age of 65 was given. Content analysis of 16 news on this subject was done through the qualitative data analysis of Maxqda. It is aimed to touch on the changing perception of aging with the content analysis.
\end{abstract}

Structured Abstract: Coronaviruses (CoV) are among the common cold-flu factors we are accustomed to seeing around us. Different genetically altered species have also been shown to cause some infections in the past. Until today, 7 types of Coronaviruses have been identified in humans, namely 229E (HCoV-229E), OC43 (HCoV-OC43), SARS-CoV, NL63, HKU1, MERS-CoV and COVID-19 (TC Ministry of Health, 2020). Among these viruses, the "Severe Acute Respiratory Syndrome" (SARS), which was effective in the Far East between 2002 and 2003 and is thought to have passed through wild cats, is a member of this family of viruses. This virus has affected up to 8000 people and caused the death of approximately $10 \%$ of the people, which is nearly 800 people, whom it affected. Similarly, "Middle East Respiratory Syndrome" (MERS), which is thought to have spread from camels and caused the death of 30\% of the people affected in Saudi Arabia and other Middle Eastern countries in 2012, is also from this virus family (Karcioğlu, 2020: $66)$.

\footnotetext{
* Dr, Kurum Tekirdağ Namık Kemal Üniversitesi, Fen Edebiyat Fakültesi, Sosyoloji Bölümü PhD, Tekirdă̆ Namık Kemal University, Faculty Of Science And Literature, Sociology

Checked by plagiarism software

Published/Yayın: 30 August/Ağustos 2020

CC BY-NC 4.0
} 
According to the definition of the Ministry of Health, (COVID-19), the new Corona Virus Disease, is a virus identified on January 13, 2020 as a result of research conducted in a group of patients who developed respiratory tract symptoms (fever, cough, shortness of breath) in late December in China. Ministry of Health, 2020). COVID-19 was declared as a "pandemic" by the World Health Organization on 11 March 2020 .

The rapid spread of the virus and its becoming a pandemic caused the world to take serious measures. Like all over the world, various measures were taken in this regard in Turkey as well. One of these measures is that the elders do not go out because the information obtained so far about COVID-19 infection has shown that some people are at higher risk of getting sick and developing serious symptoms. Among these people, the people aged 65 and over are often considered to be among the groups at risk by specialists. However, the fact that the elders are at risk does not increase the rate of virus transmission. In this sense, after the prohibition of going out to the elders, a stigmatizing attitude against the elders was observed in the society that they spread the virus.

Erving Goffman, the representative of the stigma theory and influenced by the Symbolic interactionism theory, tried to analyse human interaction and the way people present themselves in everyday life, especially in public settings. According to Goffman, each individual is at the dynamic of interaction, facing the risk of stigma one day. According to him, there are three types of stigma: First; physical obstacles or physical deformities, the latter; personality traits, third; are ethnic/ethnological or class stigma. It is the physical disability that suits the stigma type best to be handled with regard to the elders. In this regard, Goffman talks about the discrimination of the stigmatized individual and the judgment of the person to be identified abnormally based on the qualification in which he is discredited (Goffman, 2014). At this point, the status of elderly individuals who are trying to be discredited by COVID-19 stigma because of their age draws sociological attention.

Elderliness and changing elderliness perception have been discussed sociologically in recent years. The fact that the rapid industrialization and urbanization-centered modernization process has destroyed the established social structures/values has caused a change in social perspective and reactions about elderliness. In the traditional societies, "elder" is representative of abundance, fertility, dignity and experience. In modern societies, this situation has changed and, on the contrary, the elderly individual has started to be seen as the subject of uselessness, passivity, backwardness and especially be seen as a "burden" This changing perception has reduced respect for the elders. This situation has begun to cause a multifaceted series of problems for elderly individuals (Baran, 2004: 50; Bayrak, 2018: II).

In this study, document review was made from qualitative data research methods. Document review involves the analysis of written materials containing information on the subject of the research. One of the most frequently used techniques in the analysis of written documents is content analysis (Yıldırım \& Şimşek, 2006, 188-189).Content analysis is the technique of collecting text content and analysing it later. The text can be any type of written, visual or verbal element that acts as a communication medium. For example, books, newspaper or magazine articles, advertisements, speeches, official documents, films or video recordings, lyrics, photographs, clothing or works of art can be evaluated within the scope of content analysis. This analysis is used in literature, history, journalism, political science, education, psychology and many other fields. Content analysis is made without the influence of the researcher, who analyses the content of the text. For this reason, it will not be wrong to say that the content analysis is unresponsive. In addition, content analysis has a history up to a hundred years ago. In fact, in the meeting held by the German Sociological Society in 1910, Max Weber suggested using content analysis to analyse newspapers (Neuman, 2014: 199). Thus, in this study, 16 newspaper articles were analysed with content analysis. While making content analysis, MAXQDA 2020 qualitative data analysis program was used. MAXQDA is a software for the analysis of qualitative data and is therefore the abbreviation of "Computer Aided Qualitative Data", the CAQDAS family is an Analysis Software. It is also often used to index large amounts of text systematically and to code automatically (Kuckartz and Rädiker, 2019). In this study, MAXQDA Qualitative Data Analysis program was preferred to make the analyses made in this scope more systematic.

First of all, online news was collected with the restriction. Later, newspaper news was categorized and it was seen that newspaper news was categorized in four categories. These categories are warning, disrespect, reaction of the elders and reaction to disrespect. A separate categorization was made regarding the content of the news. It was observed that the content of the newspaper news, which was analysed with the

Turkish Studies, 15(4) 
basic theme of "Changing Perception of Elderliness: Elders Stigmatized with COVID-19", gathered around the topics of the reasons of the elders to go out, attitudes towards the elders, responses of elders and reactions to the behaviours.

It is understood from the news content that the elders usually go out due to compulsory reasons such as boredom or not knowing the restriction. The attitudes developed against the elders who came out showed a changing perception of elderliness. In general, people who encounter an elderly person outside have developed stigmatizing actions such as scolding, blame, exclusion, and ridicule. In response to this situation, the elders responded with physical reaction, disregard, sadness, fear, feeling guilty, or denying their age. It was seen that people who were sensitive to the events and state officials reacted to the events as a result of news content analysis. In conclusion, in this study, it is seen that with the COVID-19 pandemic, the elders have been exposed to stigma and the perception towards the elders have changed negatively.

Keywords: Sociology, COVID-19, Elderliness, Stigma, News, Maxqda.

Öz: COVID-19 Virüsünün hızlı yayılması ve bir pandemi haline gelmesi tüm dünyanın ciddi önlemler almasına sebep olmuştur. Tüm dünya da olduğu gibi Türkiye'de de bu kapsamda çeşitli önlemler alınmıştır. $\mathrm{Bu}$ önlemlerden biri de yaşlıların dışarı çıkmamasıdır. Çünkü COVID-19 enfeksiyonu ile ilgili şimdiye kadar edinilen bilgiler, bazı insanların daha fazla hastalanma ve ciddi semptomlar geliştirme riski altında olduğunu göstermiştir. Bunlardan özellikle 65 yaş ve üzerindeki kişiler etkilenme oranının fazla olmasından dolayı uzmanlar tarafından risk altındaki gruplar arasında sayılmaktadır. Ancak COVID-19 ile beraber toplumdaki yaşlı vurgusunun "yaşlılar için riskli" alandan "tehlikeli yaşll” alanına doğru çekildiği görülmektedir. Özellikle salgından sonraki alınan 65 yaş üstündekilere uygulan sokağa çıkma yasağı ile beraber yaşlılar sosyal medyada ve gündelik yaşamda saygısız davranışlara ve hatta zorbalığa maruz kalmaya başlamıştır. Bu durum onların statü ve rollerinde çeşitli kayıpların göstergesi olmaktadır. Yaşlılara saygı göstermek ve onlara değer vermek bizim önemli toplumsal özelliklerimizdendir. Türk toplumunun aile yaşamında ve geleneğinde yaşlılara saygı göstermek bulunmaktadır. Çünkü onlar geçmiş ve gelecek arasındaki en önemli bağdır. Bu çalışmada 65 yaş üstü kısıtlama gelmesi ile yaşlıların gazete haberlerinde nasıl yer aldığına bakılmıştır. Bu konuda 16 tane haberin içerik analizi Maxqda nitel veri analizi aracılığıyla yapılmıştır. Yapılan içerik analizleri ile birlikte değişen yaşlılık algısına değinmek amaçlanmaktadır.

Anahtar Kelimeler: Sosyoloji, COVİD-19, Damgalama, Yaşl11ı, Haber, Maxqda.

\section{Giriş}

Koronavirusler (CoV), etrafımızda yaygın bir şekilde görmeye alıştığımız nezle-grip etkenleri arasındadır. Geçmişte genetiği değişmiş farklı türlerinin de bazı enfeksiyonlara da yol açtığ1 görülmüştür. Günümüze kadar insanlarda 229E (HCoV-229E), OC43 (HCoV-OC43), SARSCoV, NL63, HKU1, MERS-CoV ve COVID-19 olmak üzere yedi tip Koronavirüs tanımlanmıştır (T.C. Sağlık Bakanlı̆̆ı, 2020). Bunlar arasında yakın geçmişte 2002-2003 yılları arasındaki uzak doğuda etkili olan ve yabani kedilerden geçtiği düşünülen "Şiddetli Akut Solunum Sendromu" (SARS) bu virüs ailesinin üyesidir. Bu virüs 8000 kadar kişiyi etkilemiş, etkilediği kişilerden yaklașık \%10 unu yani 800'e yakınının ölümüne sebep olmuștur. Yine benzer șekilde 2012 yılında Suudi Arabistan ve diğer Ortadoğu ülkelerinde etkilediği insanların \%30'unun ölümüne yol açan ve develerden yayıldığı düşünülen “Orta Doğu Solunum Sendromu” (MERS) de bu virüs ailesindendir (Karcioğlu, 2020: 66).

Sağlık bakanlığının tanımına göre; (COVID-19), yani yeni Koronavirüs Hastalığ 1 ilk olarak Çin'in Vuhan Eyaleti'nde Aralık ayının sonlarında solunum yolu belirtileri (ateş, öksürük, nefes darlığı) gelişen bir grup hastada yapılan araştırmalar sonucunda 13 Ocak 2020'de tanımlanan bir virüstür (T.C. Sağlık Bakanlığı, 2020). COVID-19 11 Mart 2020 tarihinde Dünya Sağlık Örgütü tarafından "pandemi" ilan edilmiştir.

Virüsün hızlı yayılması ve bir pandemi haline gelmesi tüm dünyanın ciddi önlemler almasına sebep olmuştur. Tüm dünya da olduğu gibi Türkiye'de de bu kapsamda çeşitli önlemler 
alınmıştır. Bu önlemlerden biri de yaşlıların dışarı çıkmamasıdır. ${ }^{1}$ Çünkü COVID-19 enfeksiyonu ile ilgili şimdiye kadar edinilen bilgiler, bazı insanların daha fazla hastalanma ve ciddi semptomlar geliştirme riski altında olduğunu göstermiştir. Bunlardan genellikle 65 yaş ve üzerindeki kişiler daha fazla etkilendiğinden dolayı uzmanlar tarafindan risk altındaki gruplar arasında sayılmaktadır. Ancak yaşlıların risk altında olmaları virüsü bulaştırıcılığı oranını arttırmamaktadır. Bu anlamda yaşlılara dışarı çıkma yasağı getirildikten sonra toplumda yaşlılara karşı virüsü yaydıkları yönünde bir damgalama tutumu görülmüştür.

Damgalama kuramının temsilcisi olan ve sembolik etkileşimcilik kuramından etkilenmiş olan Erving Goffman insan etkileşimini ve insanların kendilerini gündelik hayatta, özellikle kamusal ortamlarda 'sunma' biçimlerini analiz etmeye çalışmıştır. Goffman'a göre her birey bir gün damgalanma riski ile karşı karşıya kalma etkileşimin dinamiğindedir. Ona göre üç tür damgalanma bulunmaktadır: Birincisi; bedensel engeller veya fiziki şekil bozuklukları, ikincisi; kişilik özellikleri, üçüncüsü; etnik/etnolojik veya sınıfsal damgalardır. Yaşlılar ile ilgili ele alınacak damga türüne en uygun bedensel engellerle ilgili olandır. Bu konuda Goffman damgalanan bireyin itibarsızlaştırılmasından ve itibarsızlaştırıldığı vasıf üzerinden kişiyi anormal olarak tanımlayacak yargıda bulunulmasından bahsetmektedir (Goffman, 2014). Tam da bu noktada yaşlarından dolayı COVID-19 ile damgalanarak itibarsızlaştırılmaya çalışılan yaşlı bireylerin durumu sosyolojik açıdan dikkat çekmektedir.

Yaşlılık ve değişen yaşlılık algılayışı son yıllarda sosyolojik açıdan tartışılmaktadır. Hızlı sanayileşme ve kentleşme merkezli modernleşme sürecinin yerleşik toplumsal yapıları/değerleri aşındırması yaşlılığa ve yaşlılığa dair toplumsal bakış açısı ve tepkilerin de değişmesine sebep olmuştur. Geleneksel toplumlarda "yaşll", bolluğun, bereketin, saygınlığın ve tecrübenin temsilcisidir. Modern toplumlarda ise bu durum değişerek tersine yaşlı birey daha çok işe yaramazlığın, pasifliğin, geri kafalılığın ve özellikle "yük” olarak görülmenin öznesi olarak görülmeye başlanmıştır. Değişen bu algı yaşlılara duyulan saygıyı, hürmeti azaltmıştır. Bu da, yaşlı bireyler için çok yönlü bir sorunlar dizisine neden olmaya başlamıştır (Baran, 2004: 50; Bayrak, 2018: II). Bu çalışma COVID-19 sonrası yaşlılara yönelik sokağa çıkma yasağının beraberinde getirdiği damgalama ile görünürlüğü artan yaşlılık algılayışındaki değişim, 16 online gazete haberi üzerinden yapılan içerik analizi ile gösterilmiştir. Gazete haberlerinin içerik analizi MAXQDA nitel veri analizi aracılığıyla gerçekleştirilecektir.

\section{Bulgular ve Yorum}

$\mathrm{Bu}$ çalışmada nitel veri araştırma yöntemlerinden doküman incelemesi yapılmıştır. Doküman incelemesi araştırma konusu hakkında bilgi içeren yazılı materyallerin çözümlenmesini içermektedir. Yazılı dokümanların incelenmesinde en sık kullanılan tekniklerden biri içerik analizidir (Yıldırım \& Şimşek, 2006, 188-189). İçerik analizi, metin içeriğini toplama daha sonrasında analiz etme tekniğidir. Metin, bir iletişim ortamı görevi gören her türden yazılı, görsel ya da sözlü öğe olabilmektedir. Örneğin kitap, gazete veya dergi makaleleri, reklamlar, söylevler, resmî belgeler, filmler veya video kayıtları, şark1 sözleri, fotoğraflar, giyim eşyaları veya sanat eserleri içerik analizi kapsamında değerlendirilebilmektedir. Bu analiz edebiyat, tarih, gazetecilik, siyaset bilimi, eğitim, psikoloji ve benzeri pek çok alanda kullanılmaktadır. İçerik analizi metnin içeriğini analiz eden araştırmacının etkisi olmaksızın gerçekleşmektedir. Bu sebeple içerik analizi tepkisiz olduğunu söylemek yanlış olmayacaktır. Ayrıca içerik analizinin, yüz yıl önceye kadar geçmişi bulunmaktadır. Hatta Alman Sosyoloji Topluluğu'nun 1910 yılında gerçekleştirmiş olduğu toplantıda Max Weber, içerik analizini gazeteleri incelemek için kullanılmasını önermiştir (Neuman, 2014: 199). Nitekim bu çalışmada da içerik analizi ile 16 adet gazete haberi ${ }^{2}$ incelenmiştir. İçerik analizi yapılırken MAXQDA 2020 nitel veri analizi programı kullanılmıştır.

121.03 .2020 tarihinde İçişleri Bakanlığ 81 il valiliğine 65 yaş ve üzeri ile kronik rahatsıllığı bulunanlar için "İkametten ayrılma kısitlamasl/yasaklanması" konulu genelge gönderdi.

${ }^{2}$ Gazete haberlerine online olarak haberler.com sitesinden ulaşılmıştır. 
MAXQDA nitel verilerin analizi için bir yazılımdır ve bu nedenle "Bilgisayar Destekli Niteliksel Veriler" in kısaltması olan CAQDAS ailesi bir Analiz Yazılımıdır. Genellikle büyük miktarlarda metinleri sistematik olarak endekslemek ve otomatik olarak kodlamak için de kullanılmaktadır (Kuckartz ve Rädiker, 2019). Bu anlamda yapılan analizlerin daha sistematik olması için bu çalışmada MAXQDA Nitel Veri Analizi programı tercih edilmiştir.

İncelenen haberlerin geneli tablo 1'de görüldüğü üzere 65 yaş üzeri dışarı çıkma yasağının ilan edildiği 21.03.2020 tarihi ve hemen sonrasındaki 24.03.2020, 26.03.2020 tarihleri arasındaki haberleri içermektedir. ${ }^{3}$ Belirtilen tarihlerdeki haberlerin seçilmesi yaşlllara olan tutumun daha yoğun olduğu tarihler olmasından kaynaklanmaktadır. Belirtildiği gibi incelenen haberlerin çoğunluğu 21-24.03.2020 tarihlerini kapsamaktadır. Haberler seçilirken haber içeriklerinin yaşlılara getirilen kısıtlamalar ile ilgili olmasına dikkat edilmiştir.

Tablo 1: Haberlerin Tarihleri

\begin{tabular}{|c|c|c|c|}
\hline Belge grubu & Haberler & Kod & Haber Tarihleri \\
\hline Saygısızlığa tepki & haber12 & Haber tarihleri & 24.03 .202011 .56 \\
\hline Saygisızlığa tepki & haber11 & Haber tarihleri & 24.03 .202018 .06 \\
\hline Saygisızlığa tepki & haber10 & Haber tarihleri & 24.03 .202007 .52 \\
\hline Yaşlılardan reaksiyon & haber9 & Haber tarihleri & 24.03 .202013 .16 \\
\hline Yaşlılardan reaksiyon & haber13 & Haber tarihleri & 24.03 .202013 .10 \\
\hline Yaşlılardan reaksiyon & haber16 & Haber tarihleri & 23.03.2020 19.54 \\
\hline Yaşlılardan reaksiyon & haber15 & Haber tarihleri & 23.03.2020 05.50 \\
\hline Yapılan saygisızlık & haber14 & Haber tarihleri & 26.03 .202013 .57 \\
\hline Yapılan saygisızlık & haber8 & Haber tarihleri & 24.03 .202017 .50 \\
\hline Yapılan saygisızlık & haber5 & Haber tarihleri & 24.03 .202021 .42 \\
\hline Yapılan saygısızlık & haber6 & Haber tarihleri & 24.03.2020 11.17 \\
\hline Uyarı & haber7 & Haber tarihleri & 24.03 .202012 .59 \\
\hline Uyarı & haber4 & Haber tarihleri & 19.03.2020 11.44 \\
\hline Uyarı & haber3 & Haber tarihleri & 22.03 .202010 .22 \\
\hline Uyar1 & haber2 & Haber tarihleri & 23.03.2020 08.58 \\
\hline Uyarı & haber1 & Haber tarihleri & 21.03 .202013 .18 \\
\hline
\end{tabular}

\section{Tüm Haber Kategorileri}

65 yaş ve üzeri yaşlılık dönemi olarak tanımlanmaktadır. Bu sebeple bu yaş grubunun sağlığı düşünülerek COVIDD-19 ile birlikte 65 üzeri bireylere dışarı çıkma yasağı getirilmiştir. Bu durum birçok mecrada tartışılmıştır. Bu mecralardan biride gazete haberleridir. $\mathrm{Bu}$ çalışmada yaşanan sürecin belirlenen 16 online gazete haberlerinde nasıl yer aldığı ve bunun değişen yaşlılık algısı ile olan ilişkisi değerlendirilecektir.

Goffman bir bireyin, kişisel olarak tanımadığı birini toplumsal olarak tanıması ve aynı şekilde o kişi tarafindan toplumsal olarak tanınması mümkün olduğundan bahsetmektedir. Her hâlükârda, bilişsel tanımanın basit bir algısal edim olduğu, toplumsal tanımanın ise bireyin iletişim seremonisinin bir parçası olduğu bir gerçektir. Bir kişiye toplumsal kimliği nedeniyle gösterilen muamele, eğer aynı kişi bireysel kimliği kaynaklı bir şöhrete sahipse ilave bir hürmet ve hoşgörü ile zenginleşir (Goffman, 2014: 109). Yaşliların da toplumsal kimlikleri sebebiyle kazanmış oldukları hürmet ve hoşgörünün son yıllarda değiştiği görülmektedir. Bu durumun yaşanmasında Sanayi devrimi sonrasında ortaya çıkan yaşam şeklinin etkisi bulunmaktadır. Çünkü toplumların bu süreçte aldıkları mesafe ile birlikte yaşlıların statü ve saygınlıklarını da değişmiştir. Teknolojik

\footnotetext{
${ }^{3}$ Kullanılan bir haber bu tarihler arasında değildir. Ancak bu haberlerde yasağın sinyallerinin verildiği 19.03.2020 tarihli haberdir.
} 
gelişmeler, göç, kentleşme, tüketim kültürü, modernleşme vb. etkenler geleneksel toplumlarda hemen hemen her yaşlıya atfedilen saygınlık, değer ve önemin bireyler düzeyine indirgenerek genetik ve duygusal bağlılıklar çerçevesinde dikkate alınır hale gelmesine sebep olmuştur (Özkul, \& Kalayc1, 2015: 262). Özellikle pandemi sürecinde bu durumun görünürlüğü artmıştır. Bu sebeple bu çalışmada COVID-19 sebebiyle getirilen kısıtlılıkla daha da görünür olan yaşlılık algılayışındaki değişimi açıklamak amaçlanmaktadır. Bu amaç doğrultusunda araştırmanın temel soruları: yaşlılara yönelik anlayış değişmiş midir? COVID-19 süreci ile beraber yaşlılar bir damgalanmaya maruz kalmış mıdır?

\section{Harita 1: Tüm Haber Kategorileri}

\section{Haberler Tek-Vaka Modeli}

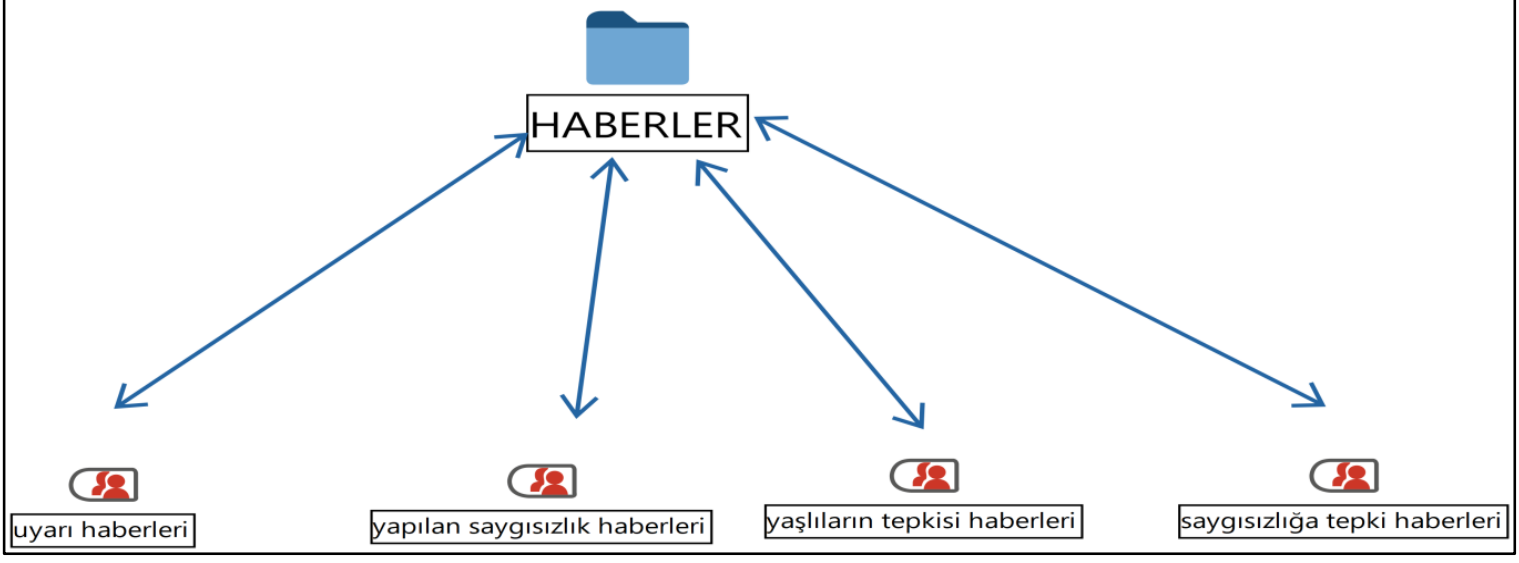

Analiz edilen tüm haberler öncelikle kendi arasında kategorize edilmiștir. Daha sonrasında kategorilere ayrılan haberlerin "Değişsen Yaşlılık Algısı: COVID-19 İle Damgalanan Yaşlılar" temel temasıyla analizi yapılmıştır. (harita 2) Haberlerin kategorileri harita 1'de görüldüğ̈̈ gibi uyarı haberleri, yapılan saygısızlık haberleri, yaşlıların tepkisi haberleri ve saygısızlığa tepki haberleri olmak üzere dört tanedir. Belirtildiği gibi yapılan analizlerde belge grubu olarak temelde bu kategorideki ayrımlar baz alınmıştır.

\section{Değișen Yașlılık Algısı: COVID-19 ile Damgalanan Yaşlılar}

Dünya nüfusu hızla yaşlanmaya başlaması ülkemiz de başta olmak üzere tüm dünyayı etkilemektedir. Bu durum yaşl11ık olgusunu öne çıkarmaktadır. Modern dünyada yaşlılık olgusunun önem kazanması toplumsal olarak yaşlılık algısının değişmesine de sebep olmuştur (Köroğlu \& Köroğlu, 2015: 812). Geleneksel toplumlarda yaşlılara üstlendikleri, ikinci kuşağın yetiştirilmesi, kültür aktarımı, kültürün korunması gibi roller atfedilmesinden dolayı değer görmektedir. Ancak modern toplumlarda geleneksel toplumlarda üstlendiği statü kaybeden dolayısıyla rol kaybını yaşayan yaşlılar aynı değeri görememektedir (Bayrak, 2018: 33). Modern dünya üretici ve tüketicilerin beraber oluşturduğu bir yerdir. Yaşlılık ise bu oluşumun dışında bulunmaktadır. Dolayısıyla böyle bir dünyada yaşlılar kendilerini gerçekleştirme olanağını bulamamaktadır. Ayrıca toplumdaki değişen yaşlılık algısı nedeniyle ayrımcılığa maruz kalmaktadır (Kalaycıoğlu, 2003:7). 
Harita 2: Değişen Yaşlılık Algısı: COVID-19 İle Damgalanan Yaşlılar

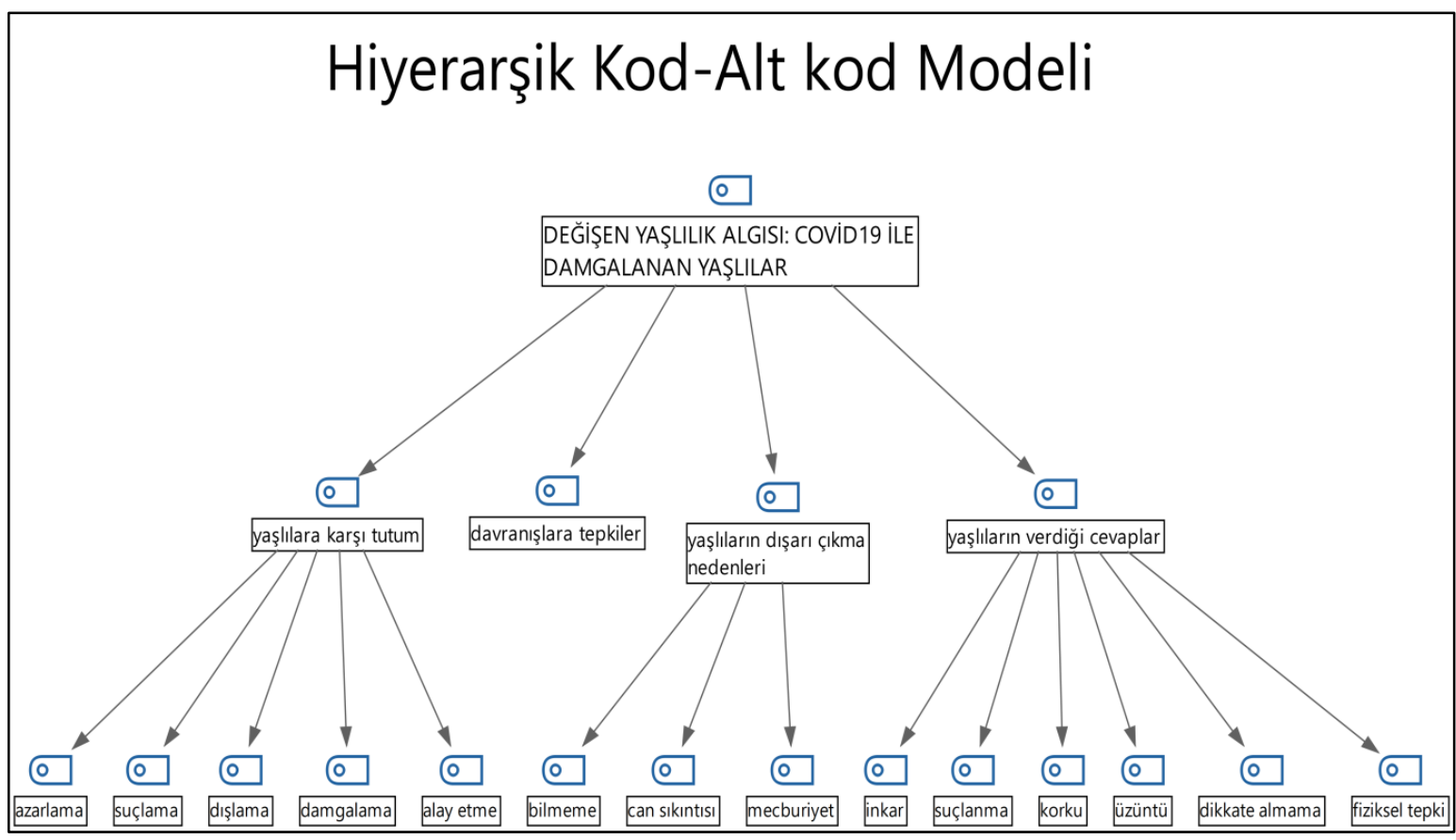

Değişen Yaşlılık Algısı: COVID-9 İle Damgalanan Yaşlılar temel teması ile harita 2'de görülen kategori ve kodlar oluşturulmuştur. Buna göre öncelikle gazete haberleri analiz edilerek haberlerin kategorizasyonu yapılmıştır (harita1). Sonrasında on altı gazete haberlerinin içeriğine göre "yaşlılara karşı tutum", "davranışlara tepkiler", "yaşlıların dışarı çıkma nedenleri", "yaşlıların verdiği cevaplar" olmak üzere dört kategori oluşturulmuştur. Bu kategorilerin altında kodlar harita sırasına göre; "yaşlılara karşı tutum" kategorisinin kodları "zorlama", "suçlama", "dışlama", "damgalama" ve "alay etmedir". Davranışlara tepkiler kategorisi oluşturulmamıştır. Bu kategorinin altında kodlar oluşturulmamıştır. "Yaşlıların dışarı çıkma nedenleri" kategorisinin altında "bilmeme", "can sıkintısı", "mecburiyet” kodları oluşturulmuştur. Son olarak "yaşlıların verdiği cevaplar" kategorisinin altında "inkâr", "suçlama”, "korku”, "üzüntü”, "dikkate almama", "fiziksel tepki" kodları oluşturulmuştur. Tüm bu kodların alt kodları ile birlikte detaylı incelemesi harita ve tablolar aracığı ile yapılmıștır (harita3, harita4, harita5, harita6, tablo2, tablo3, tablo4, tablo5).

\subsection{Yaşılıların Dışarı Çıkma Nedenleri}

Yaşlıların COVID-19 ile getirilen yasakla beraber bazen dışarı çıktıkları görülmektedir. $\mathrm{Bu}$ da gazete haberlerine yansımıştır. Yapılan içerik analiziyle yaşlıların dışarı çıkma sebepleri harita3 ve tablo2' ilgili kategori, kod ve alt kodlar ile belirtilmiştir. Goffman bu durumu "Damga: Örselenmiş Kimliğin İdare Edilişi Üzerine Notlar" adlı kitabında toplumsal kimliğinden

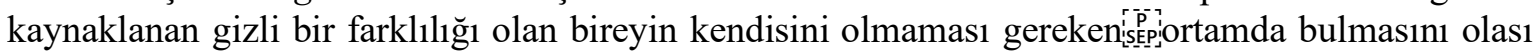
bir durum olarak açıklamaktadır. Ona göre; yasak ya da sınırı aşan ortamlar; yani farklılığı olan kişinin olduğu gibi olmasının yasaklandığ is sẹpive ifşa olmanın kovulmak anlamına geldiği yerler vardır (Goffman, 2014: 123). Bu anlamda yaşlıların yasak olmasına rağmen dışarı çıktıkları görülmektedir.

Yaşlıların dışarı çıkmalarında etkili olan sebepler bulunmaktadır. Yapılan araştırmalarda yaşlıların eve bağlı olmamaları, sık sık dışarı çıkmaları fiziksel sağlıkla yakından ilgilidir. Bunun yanında dışarı çıkmaları fiziksel açıdan faydalı olduğu kadar onların sosyalleşmeleri için de önemlidir. Onların sosyal yaşantılarını sürdürmeleri iyi hal göstergesidir. Sosyal yaşantının devamı yaşlanma ile beraber yaşanan rol ve statü kayıplarını dengelemektedir (İçli 2010: 12). Ayrıca 
yaşlıların dışarı çıkma nedenleri değerlendirilirken temel kavram "günlük rutinler" olmalıdır. Çünkü kişiyi çeşitli sosyal ortamlara bağlayan bu rutinleridir (Goffman, 2014: 136). Bu anlamda yaşlıların dışarı çıkmalarında normal süreçte yaptıkları rutinler önemlidir. İçerik analizi yapılan gazete haberlerinde görüldüğü üzere yaşlılar genellikle mecburi ihtiyaçlarından, can sıkıntısından ya da normalde alışılmışın dışına çıkmalarından kaynaklı bilmemeden dolayı dışarı çıkma eğilimi göstermektedir. Yani bir anlamda yaşlılar günlük rutinlerinin dışına çıkmak istememektedir.

Harita 3: Yaşlıların Dışarı Çıkma Nedenleri

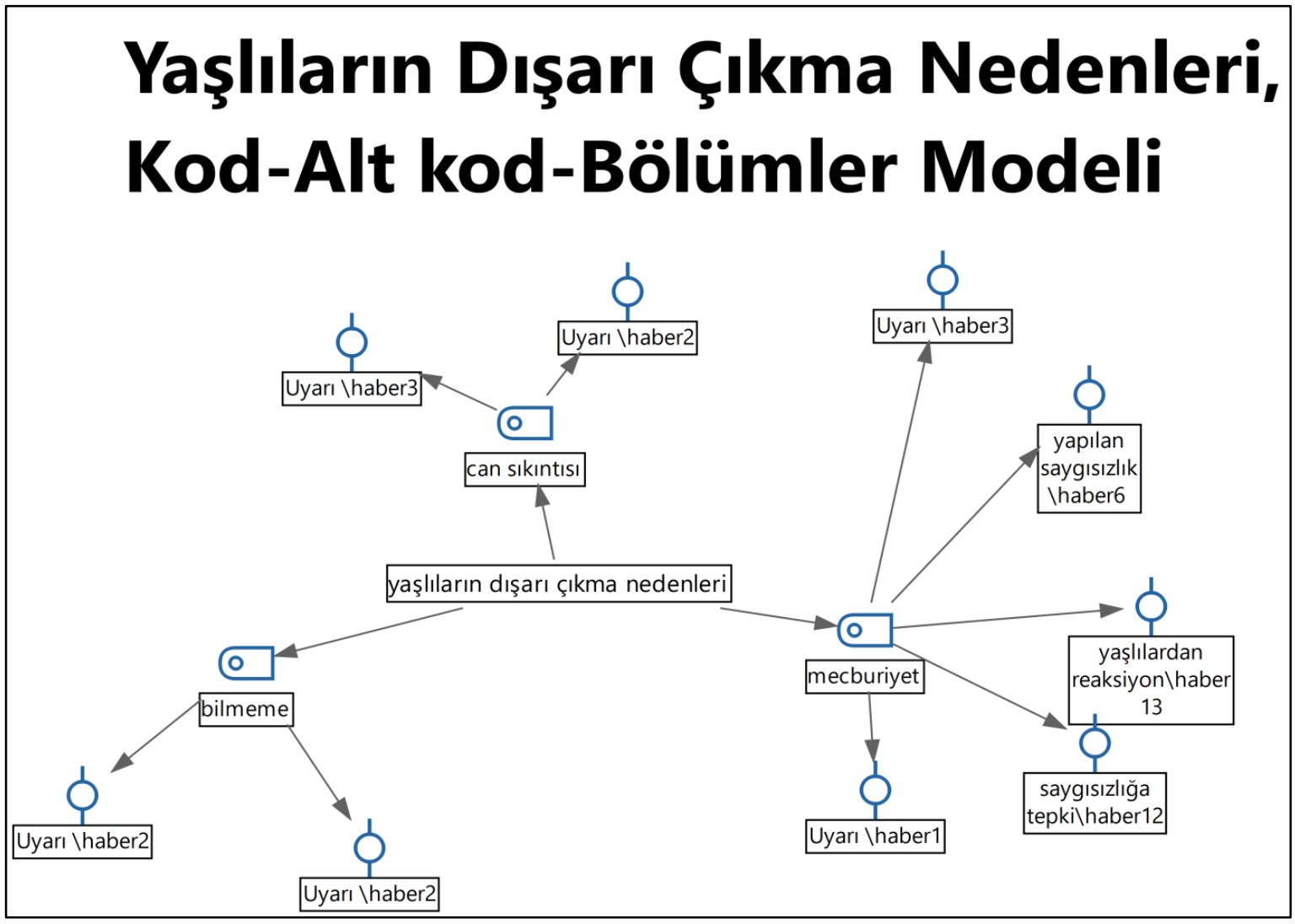

Yaşlıların dışarı çıkma kategorisi altında üç tane kod belirlenmiştir. Bunlar tablo 3’te görüldüğü gibi mecburiyet, can sıkıntısı ve bilmemedir. Mecburiyet kodunda uyarı, yapılan saygısızlık ve yaşlılardan reaksiyon (haber1, haber3, haber6, haber12, haber13); can sıkıntıs1 kodunda uyarı haberlerinden (haber2, haber3); bilmeme kodunda uyarı haberlerinden (haber2) kodundan faydalanılmıştır. 


\begin{tabular}{|c|c|c|c|}
\hline $\begin{array}{l}\text { Belge } \\
\text { Grubu }\end{array}$ & $\begin{array}{l}\text { Belge } \\
\text { Adı }\end{array}$ & KategorilKod & Alt Kod \\
\hline Uyar1 & Haber1 & $\begin{array}{l}\text { Yaşlıların Dişarı } \\
\text { Çıkma } \\
\text { NedenlerilMecburiyet }\end{array}$ & $\begin{array}{l}\text { Bol bol temizlik olacak, evi havalandıracağız. } \\
\text { Bunların hiç birisi yok, dışarı çıkmaya mecburuz. } \\
\text { Ekmek aldım kim gidecek almaya eşim de zaten } \\
\text { evden dışarı çıkamıyor. Bir şey olmaz deyip } \\
\text { geziyorlar, Allah'ın izniyle geçecek }\end{array}$ \\
\hline Uyarı & Haber3 & $\begin{array}{l}\text { Yaşlıların Dışarı } \\
\text { Çıkma } \\
\text { NedenlerilMecburiyet }\end{array}$ & $\begin{array}{l}\text { Dışarıya çıkmayın dediler ama çıktım Ekmek, tavuk } \\
\text { ve içecek aldım }\end{array}$ \\
\hline $\begin{array}{l}\text { Yapılan } \\
\text { Saygisızlık }\end{array}$ & Haber6 & $\begin{array}{l}\text { Yaşlıların Dışarı } \\
\text { Çıkma } \\
\text { NedenlerilMecburiyet }\end{array}$ & $\begin{array}{l}\text { "Ben hastaneye geldim, otobüse binip eve gideceğim } \\
\text { ama otobüs beni almadı" }\end{array}$ \\
\hline $\begin{array}{l}\text { Yaşlilardan } \\
\text { Reaksiyon }\end{array}$ & Haber13 & $\begin{array}{l}\text { Yaşlıların Dişarı } \\
\text { Çıkma } \\
\text { NedenlerilMecburiyet }\end{array}$ & $\begin{array}{l}\text { Yasağa rağmen dışarı çıkan yaşlı bir vatandaş } \\
\text { kendisini evine bırakmak isteyen polislere, "Bırakın } \\
\text { beni yayan gideyim, dizlerim açılsın" dedi. }\end{array}$ \\
\hline $\begin{array}{l}\text { Saygısızlığa } \\
\text { Tepki }\end{array}$ & Haber12 & $\begin{array}{l}\text { Yaşlıların Dışarı } \\
\text { Çıkma } \\
\text { NedenlerilMecburiyet }\end{array}$ & $\begin{array}{l}\text { Sosyal medyada yaşlılara yönelik alaycı videolar } \\
\text { olsa da kamu görevlileri } 65 \text { yaş üzerindekilerin tüm } \\
\text { ihtiyaçlarını gidermeye çalışıyor. O videolardan } \\
\text { birinde yaşlı adam zabıta memurundan isteklerini } \\
\text { sıralarken poğaça da istediğini belirtiyor ve şunları } \\
\text { söylüyor "1 kilo pırasa, bizim pazarda taze fasulye } \\
\text { gördüm yarım kilo da taze fasulye. Bir de poğaça } \\
\text { alır mısın poğaça? Peynirli veya zeytinli fark } \\
\text { etmiyor. } 4 \text { tane alsan yeter." Amcanın naif bir } \\
\text { şekilde poğaça istemesi ise büyük ilgi gördü. }\end{array}$ \\
\hline Uyarı & Haber2 & $\begin{array}{l}\text { Yaşlıların D Dışarı } \\
\text { Çıkma NedenlerilCan } \\
\text { Sıkıntısı }\end{array}$ & Evinden çıkan 69 yaşındaki adam "bunaldım" dedi \\
\hline Uyar1 & Haber3 & $\begin{array}{l}\text { Yaşlıların } \quad \text { Dışarı } \\
\text { Çıkma NedenlerilCan } \\
\text { Sıkıntısı }\end{array}$ & $\begin{array}{l}\text { "Dışarıya çıkmayın dediler ama çıktım hava } \\
\text { alacağım" }\end{array}$ \\
\hline Uyar1 & Haber2 & $\begin{array}{l}\text { Yaşlıların Dişarı } \\
\text { Çıkma } \\
\text { NedenlerilBilmeme }\end{array}$ & $\begin{array}{l}\text { Yaşlı vatandaşın kimliğini kontrol eden polis } 74 \\
\text { yaşında olduğunu görünce neden dışarıya çıtığını } \\
\text { sordu. Yaşlı adamın "eve gidiyorum saat } 17.00 \text { 'e } \\
\text { daha var" dedi }\end{array}$ \\
\hline Uyarı & Haber2 & $\begin{array}{l}\text { Yaşlıların Dışarı } \\
\text { Çıkma } \\
\text { NedenlerilBilmeme }\end{array}$ & $\begin{array}{l}\text { Vatandaşların kimliklerini tek tek kontrol edildiği } \\
\text { esnada } 64 \text { yaşındaki bir vatandaşın yaş sınırının } \\
\text { altında kaldığını söylemesi üzerine polis, "Yaş } \\
\text { yasağı yok ama sonuçta virüs var, sağlığınız için } \\
\text { söylüyorum" diyerek uyarıda bulundu. }\end{array}$ \\
\hline
\end{tabular}

COVID-19 ile birlikte getirilen yasağa rağmen dışarı çıkma eğiliminde olan yaşlıların dışarı çıkma nedenlerinin başında "mecburiyet" olduğu görülmektedir. Öyle ki gazete haberlerinin içeriği incelendiğinde dışarı çıkan yaşlıların bazılarının ekmek ya da zaruri ihtiyaçlarını almaya çıktıklarını, kendisinden başka ekmek almaya gidecek kişi olmadığ yanında daha zaruri olan sağlık ihtiyaçları ya da günlük egzersizleri için dışarı çıktıkları için dışarı çıktıkları görülmektedir. Ayrıca yaşlıların sokağa çıkmamasına yönelik ihtiyaçlarını karşılamak için görevlendirilenlerden yine mecburi ihtiyaçlarının temini için yardım aldıkları gazete haberlerinin içeriğinden anlaşılmaktadır. Yapılan içerik analizi sonucu yaşlıların dışarı çıkma sebeplerinden ikincisinin "can sıkıntısı" olduğu görülmektedir. Yaşlilar genellikle bunalma ve hava almak isteme gerekçesiyle dışarı çıkmak istemektedir. Gazete haberlerinde son olarak yaşlıların dışarı çıkma nedeni getirilen yasağı "bilmemedir." Buna göre yaşlılar bazı yaşlılar mesai 
saatinde yasağın bittiğini zannettiklerini ve bir yaş ile bu yasağın kendine geçerli olmadığını belirtmektedir.

Yaşl11ık döneminde yaşlı bireyler çevreleri ile sürekli iletişim içinde bulunmak, yeni kişilerle tanışmak ve bazı sosyal kültürel aktivitelere katılmak istemektedir. Bunun içinde sosyal çevreye katılmak ve böylece sosyal ilişkiler ağını genişletmek istediği içindedirler. Dolayısıyla sosyal hayata katııım onların dışlanmışlık ve yalnızlık halinden çıkmalarına yardımcı olacaktır. Bu anlamda sosyal bütünleşme ve sosyal katılımın yaşlılık dönemi için daha da önemli olduğunu söylemek gerekmektedir (İçli, 2016; Bayram, 2018). Ancak COVİD-19 ile birlikte getirilen sınırlama ile sosyal süreçleri sekteye uğramıştır. Nitekim yapılan analizlere bakıldığında yaşlıların dışarı çıkma sebeplerinden birinin can sıkıntısı olduğu görülecektir. Haber:2 "Evinden çıkan 69 yaşındaki adam "bunaldım" dedi."

\subsection{Yaşlılara Karşı Tutum}

Sokağa çıkma yasağından sonra toplumun yaşlılara gösterdiği tepkilerin gazete haberlerine yansımasının analizi harita4 ve tablo3' te gösterilmiştir. Sosyoloji bazen, hepimizin bir grubun bakış açısından konuştuğumuzu söylemektedir. Damgalı kişinin özel durumu ise toplumun ona büyük bir grubun üyesi olduğunu söylemesidir. Bu da onun normal bir insan olduğu anlamına gelir ama aynı zamanda is septoplum, damgalı bireye onun bazı açılardan "farkll" olduğunu ve bu

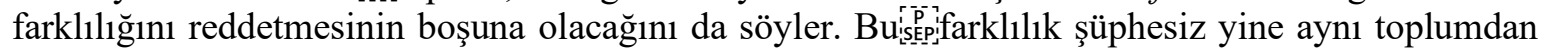
kaynaklanır; çünkü normal koşullarda bir fark, eğer daha öncesinde müşterek surette kavramsallaştırılmamışsa bir mesele hâline gelmez (Goffman, 2014: 174). Yaşlılara karş1 geliştirilen tavırda da farklıya vurguda bulunulmaktadır. Yani pandemi döneminde her ne kadar toplumsal kodlarımıza da atıfta bulunup yaşlılara karşı damgalayıcı davranışlarda olmaması gerekildiği bilinse de, yine onlara karşı tavırlar Goffman'ın deyimiyle farklı ya da damgalı olduklarını vurgular nitelikte olmuştur.

Yaşl11ığın sosyolojik boyutlarından biride toplumda belirli bir yaş grubuna verdiği değerle ilgilidir. Sosyolojik yaşlanma; bireylerin yaşam boyu bir yandan yeni roller üstlenirken bir yanda da eski rollerini terk ettiğinden dolayı toplumda tekrarlanan bir süreçtir. Toplum bir bireye statü ve o statüye uygun roller vermektedir. Bu roller kişilerin yaşları ile ilgili ve yaşamlarının belli bir dönemini kapsayan sosyal yönlerini tanımlamaktadır. Toplum bir anlamda kendi kabulleri çerçevesinde verdiği rollerin tanımlarını yapmaktadır. Bu açıdan yaşlının kim olduğunu toplum tayin etmektedir (İnce, 2012: 20). Dolayısıyla yaşlılara karşı geliştirilen tutumları da toplum belirlemektedir.

Kalaycıŏglu vd. yaşlılar ile ilgili yaptığı çalışmanın sonuçlarına göre; toplumumuzda giderek olumsuzlaşan bir yaşlılık tutum ve söylemi bulunmaktadır. Bu olumsuz söylemlere göre ileri yaştaki bireyler, artık nüfus olarak görülmekte ve yaşl1lık bir kusur, özür, zafiyet ya da hastalık olarak algılanmaktadır. Yaşlılık söylemleriyle doğru orantılı olarak, toplumda yaş ayrımcılığ bulunmaktadır. Yaşlıların toplumsal yaşama dâhil edilmelerinin önündeki engelleri kaldırılmak yerine ileri yaşta olmak bir kusur olarak gösterilmektedir. Ayrıca yaşlılar toplumsal yaşamdan dışlanarak, onların aktif olabilme yeteneği kaybolma durumuna getirilmektedir (Kalaycioğlu vd., 2003:125). 
Harita 4: Yaşlılara Karşı Tutum

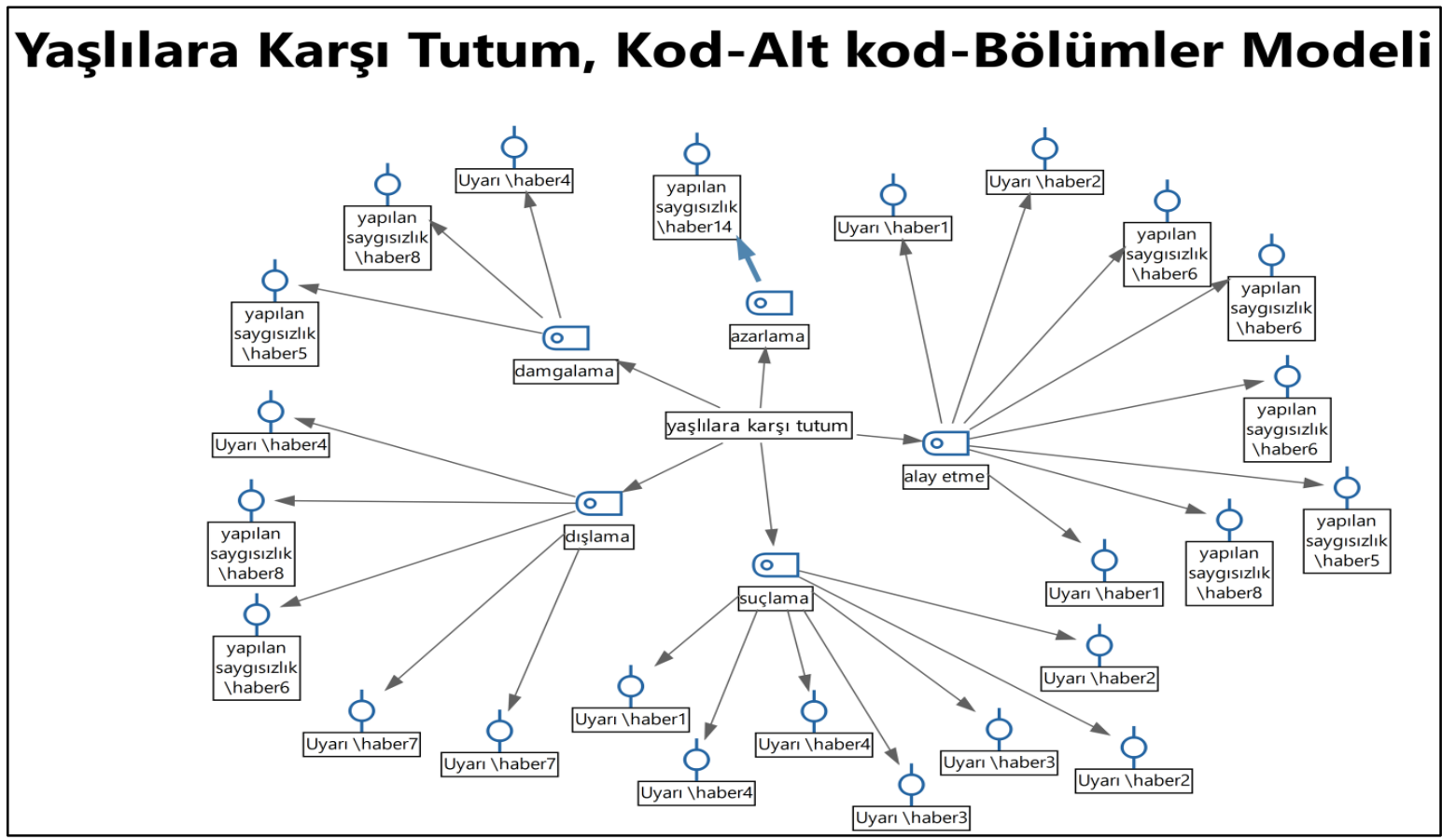

Yaşlılara karşı tutum kategorisi altında 5 kod oluşturulmuştur. Bunlar alay etme, damgalama, dışlama, suçlama ve azarlamadır. Alay etme kodunda uyarı ve yapılan saygısızlık haberlerinden (haber1,haber8, haber5, haber6, haber2); damgalama kodunda uyar1 ve yapılan saygısızlık haberlerinden (haber4, haber5, haber8); dışlama kodunda uyarı ve yapılan saygısızlık haberlerinden (haber4, haber6, haber7, haber8); suçlama kodunda uyarı haberlerinden (haber1, haber2, haber3, haber4); azarlama kodunda ise yapilan saygisizlik haberlerinden (haber14) faydalanılmıştır. Yaşlılara karşı tutum kategorisinin altında tüm kodlar ve haberlere bakıldığında hepsinin bir çeşit damgalama olduğu görülmektedir.

Tablo 3: Yaşlıların Karşı Tutum Kategori, Kod, Alt Kod Tablosu

\begin{tabular}{|c|c|c|c|}
\hline $\begin{array}{l}\text { Belge } \\
\text { Grubu }\end{array}$ & $\begin{array}{l}\text { Belge } \\
\text { Adı }\end{array}$ & KategorilKod & Alt Kod \\
\hline Uyarı & Haber1 & $\begin{array}{l}\text { Yaşlılara Karş1 } \\
\text { Tutum\Alay Etme }\end{array}$ & $\begin{array}{l}\text { Korona virüse karşı alınan önlemler kapsamında yaşlılar } \\
\text { evden çımamaları yönünde uyarılırken, parklarda oturan } \\
\text { yaşlılar açılklamalarıyla şaşırttı. Kimi yeni geldiğini kimileri } \\
\text { ekmek almaya çıktığını söyleyen yaşlılar, birbirlerine kolonya } \\
\text { ikram etmeyi de ihmal etmedi. }\end{array}$ \\
\hline Uyarı & Haber1 & $\begin{array}{l}\text { Yaşlilara Karşı } \\
\text { Tutum\Alay Etme }\end{array}$ & $\begin{array}{l}\text { Uyarılara rağmen parklarda banklarda oturan yaşlılar } \\
\text { cevaplarıyla da şaşırttı. }\end{array}$ \\
\hline Uyarı & Haber2 & $\begin{array}{l}\text { Yaşlilara Karşı } \\
\text { Tutum\Alay Etme }\end{array}$ & $\begin{array}{l}\text { Uyarıları dikkate almayan adam motosikletine binerek ara } \\
\text { sokağa girip hızla gözden kayboldu. Yaşlı adamın kaçı̧ı } \\
\text { vatandaşları güldürdü. }\end{array}$ \\
\hline $\begin{array}{l}\text { Yapılan } \\
\text { Saygisızlık }\end{array}$ & Haber6 & $\begin{array}{l}\text { Yaşlilara Karşı } \\
\text { Tutum\Alay Etme }\end{array}$ & $\begin{array}{l}\text { Söz konusu videoda, şahıs yolda yürüyen yaşlının önünü } \\
\text { kesiyor ve "Amcacım yaş kaç dışarıda geziyorsunuz?" diye } \\
\text { soruyor. }\end{array}$ \\
\hline $\begin{array}{l}\text { Yapılan } \\
\text { Saygısızlık }\end{array}$ & Haber6 & $\begin{array}{l}\text { Yaşlilara Karşı } \\
\text { Tutum\Alay Etme }\end{array}$ & $\begin{array}{l}\text { Bunun üzerine şahıs, "Normalde size cezai işlem } \\
\text { uygulamamız gerekiyor, bu seferlik sizi affedelim. Evde kal, } \\
\text { evde kal" diyerek tepki gösteriyor. }\end{array}$ \\
\hline
\end{tabular}




\begin{tabular}{|c|c|c|c|}
\hline $\begin{array}{l}\text { Yapılan } \\
\text { Saygısızlık }\end{array}$ & aber6 & $\begin{array}{l}\text { Yaşlilara Karşı } \\
\text { Tutum\Alay Etme }\end{array}$ & $\begin{array}{l}\text { Kullanıcının, diyalog esnasında kullandığı ses tonu birçok } \\
\text { kişi tarafından saygısılık olarak algılanırken söz konusu } \\
\text { şahıs, çektiği bu videoyu \#evdekal etiketi ile sosyal medya } \\
\text { hesabında paylaştı. }\end{array}$ \\
\hline $\begin{array}{l}\text { Yapılan } \\
\text { Saygısızlık }\end{array}$ & 5 & $\begin{array}{l}\text { Yaşlilara Karşı } \\
\text { Tutum\Alay Etme }\end{array}$ & $\begin{array}{l}\text { Bağcılar'da, yaşlı bir vatandaşa zorla maske takıp başına } \\
\text { kolonya döken şüpheli gözaltına alındı. }\end{array}$ \\
\hline $\begin{array}{l}\text { Yapılan } \\
\text { Saygısızlık }\end{array}$ & aber8 & $\begin{array}{l}\text { Yaşlilara Karşı } \\
\text { Tutum\Alay Etme }\end{array}$ & $\begin{array}{l}\text { Zonguldak'ta kendisini almayan toplu taşıma aracının önüne } \\
\text { yatarak hareket etmesini engelleyen yaşlı kadını videoya } \\
\text { çeken ve hakaret eden } 2 \text { kişi, polis ekiplerince gözaltına } \\
\text { alındı. }\end{array}$ \\
\hline Uyarı & aber4 & $\begin{array}{l}\text { Yaşlılara Karşı } \\
\text { Tutum\Damgalama }\end{array}$ & $\begin{array}{l}\text { Korona virüsünün yaşlı insanlarda ölüm ile sonuçlanması ve } \\
\text { kalabalık alanda birçok yaşlının oturması, virüsün } \\
\text { yayılmasını arttırabilir olması üzerine belediye ekipleri yeni } \\
\text { bir tedbir aldı. }\end{array}$ \\
\hline $\begin{array}{l}\text { Yapılan } \\
\text { Saygisızlık }\end{array}$ & Haber5 & $\begin{array}{l}\text { Yaşlilara Karşı } \\
\text { Tutum\Damgalama }\end{array}$ & $\begin{array}{l}\text { Bakırköy Cumhuriyet Başsavcılığı, bir kişinin yaşlı bir } \\
\text { vatandaşı durdurup zorla maske taktığı ve başına kolonya } \\
\text { döktüğ̈ü görüntülerin sosyal medyada yer alması üzerine } \\
\text { soruşturma başlattı. }\end{array}$ \\
\hline $\begin{array}{l}\text { Yapılan } \\
\text { Saygisızlik }\end{array}$ & h & $\begin{array}{l}\text { Yaşlilara Karşı } \\
\text { TutumWDamgalama }\end{array}$ & $\begin{array}{l}\text { Otobüse ait kamera kaydını da inceleyen ekipler, videoyu } \\
\text { çeken kişi ile görüntülerde "Benden uzak dur. Sende korona } \\
\text { var." diyerek yaşlı kadından kaçan kişiyi belirledi. }\end{array}$ \\
\hline Uyarı & h & $\begin{array}{l}\text { ara Karşı } \\
\text { aDişlama }\end{array}$ & $\begin{array}{l}\text { Denizli'de yaşlıların koronavirüsle ilgili tüm uyarılara rağmen } \\
\text { Bayram Yeri Meydanı'ndaki banklarda oturmalara devam } \\
\text { etmesi üzerine belediye ekipleri çözümü bankları sökmekte } \\
\text { buldu. }\end{array}$ \\
\hline Uyarı & aber7 & $\begin{array}{l}\text { Yaşlilara Karşı } \\
\text { Tutum\Dişlama }\end{array}$ & $\begin{array}{l}\text { Bursa'da bünyesinde } 94 \text { minibüs bulunan ilçe kooperatifi } \\
\text { araçlarına binecek yaşlılara kimlik sorup } 65 \text { yaş üstünü } \\
\text { araçlarına almıyor. }\end{array}$ \\
\hline Uyar1 & $\mathrm{Hab}$ & $\begin{array}{l}\text { Yaşlilara Karşı } \\
\text { Tutum\Dişlama }\end{array}$ & $\begin{array}{l}\text { Minibüsçü Bülent Yörü; "Ben de aracıma binen yaşlılara } \\
\text { kimlik sorarak } 65 \text { yaş üstü olanları aracıma almıyorum. }\end{array}$ \\
\hline $\begin{array}{l}\text { Yapılan } \\
\text { Saygisızlik }\end{array}$ & aher6 & $\begin{array}{l}\text { Yaşlilara Karşı } \\
\text { Tutum\Dışlama }\end{array}$ & $\begin{array}{l}\text { "Ben hastaneye geldim, otobüse binip eve gideceğim ama } \\
\text { otobüs beni almadı" }\end{array}$ \\
\hline $\begin{array}{l}\text { Yapılan } \\
\text { Saygisızlık }\end{array}$ & & $\begin{array}{l}\text { Yaşlilara Karşı } \\
\text { Tutum\Dişlama }\end{array}$ & $\begin{array}{l}\text { Zonguldak'ta yaşlı bir kadın, yeni tip koronavirüs (Kovid-19) } \\
\text { tedbirleri kapsamında } 65 \text { yaşında olduğu gerekçesiyle toplu } \\
\text { taşıma aracına alınmadı. }\end{array}$ \\
\hline Uyarı & $\mathrm{H}$ & $\begin{array}{l}\text { ara Karşı } \\
\text { ISuçlama }\end{array}$ & $\begin{array}{l}\text { Koronavirüs salgınına karşı yapılan uyarılara rağmen } \\
\text { evlerinden çıkarak parklara akın eden yaşlılardan bazıları, } \\
\text { "Neden dışarı çıkıyorsunuz?" sorusuna verdikleri yanıtlarla } \\
\text { pes dedirtti. }\end{array}$ \\
\hline Uyarı & $\mathrm{H}$ & $\begin{array}{l}\text { ra Karşı } \\
\text { Suçlama }\end{array}$ & $\begin{array}{l}\text { Koronavirüs salgınına karşı alınan önlemler çerçevesinde } \\
\text { sokağa çıkmaları yasaklanan } 65 \text { yaş üstü vatandaşlarımızdan } \\
\text { bazıları polis ekiplerine yakalanınca sundukları bahanelerle } \\
\text { pes dedirtti. }\end{array}$ \\
\hline Uyarı & Haber2 & $\begin{array}{l}\text { Yaşlilara Karşı } \\
\text { TutumISuçlama }\end{array}$ & $\begin{array}{l}\text { Uyarı esnasında yaşlı adamın "o kadar büyük değilim" } \\
\text { diyerek polisi ikna etmeye çalışması ise salgını ciddiye } \\
\text { almadıklarını gözler önüne serdi. }\end{array}$ \\
\hline Uyarı & Haber3 & $\begin{array}{l}\text { Yaşlilara Karşı } \\
\text { Tutum\Suçlama }\end{array}$ & $\begin{array}{l}\text { Ancak Beyoğlu Kasımpaşa'da } 65 \text { yaş üstü yaşlılar bu yasağa } \\
\text { uymadı. }\end{array}$ \\
\hline Uyarı & Haber3 & $\begin{array}{l}\text { Yaşlilara Karşı } \\
\text { TutumISuçlama }\end{array}$ & $\begin{array}{l}\text { Semtteki yaşlılar sabahın erken saatlerinde kendilerine sokağa } \\
\text { attı. }\end{array}$ \\
\hline Uyar1 & Haber4 & $\begin{array}{l}\text { Yaşlilara Karşı } \\
\text { Tutum\Suçlama }\end{array}$ & $\begin{array}{l}\text { Türkiye'de } 191 \text { kişide görülen koronavirüste en riskli grup } \\
\text { yaşlılar. Ancak tüm uyarılara rağmen bazı yaşlılar evlerinden } \\
\text { çıkıor, toplu halde vakit geçiriyorlar. }\end{array}$ \\
\hline
\end{tabular}




\begin{tabular}{|c|c|c|c|}
\hline Uyarı & Haber4 & $\begin{array}{l}\text { Yaşlılara Karşı } \\
\text { TutumlSuçlama }\end{array}$ & $\begin{array}{l}\text { Bankların sökülmesinin ardından meydan bomboş kaldı. } \\
\text { Çevredeki vatandaşlar ise uygulamanın iyi olduğunu } \\
\text { söyleyerek, "Güzel bir uygulama oldu çünkü arkadaşlar tam } \\
\text { bilinçlenmedi sanırım. Bir birimize mesafe koymamız } \\
\text { gerekirken yine burada bilinçsizce oturmalar oluyor. Onun } \\
\text { için virüs bulaştırmama açısından güzel bir uygulama" } \\
\text { ifadelerini kullandı. }\end{array}$ \\
\hline Yapilan & Haber & Yaşlilara & Twitter'da İzmir Çevirme Radar sayfası tarafından paylaşılan \\
\hline Saygısızlık & 14 & Tutum\Azarlama & $\begin{array}{l}\text { ve Manisa Otogarı'nda çekildiği belirtilen videoda polis } \\
\text { memuru yaşlı adama "Otur yerine, sen kimsin lan? Yaşından } \\
\text { başından utan, devletin memuruna.. Feryat ettirmeyeceksin. } \\
\text { Bana bağıramazsın. Yaşlı maşlı yok devletin memurunu } \\
\text { bilecek." diye bağırdığı duyuluyor. }\end{array}$ \\
\hline
\end{tabular}

COVID-19 ile beraber getirilen yaşlıların sokağa çıkma yasağına yönelik yaşlılara karşı geliştirilen gazete haberlerine yansıyan tutumun ilki "alay etme” olduğu görülmektedir. Goffman bu konuda kişinin, kasten ya da farkında olmaksızın kendisi hakkında açığa çıkan şeyden dolayı gözden düşürülmeye maruz kalması muhtemel olduğunu söylemektedir (Goffman, 2014: 117). Nitekim Dışarı çıkan yaşlıların birbirlerine kolonya tutmaları, verdikleri cevapların şaşkınlıkla karşılanması, yaşlıların kaçmasına gülünmesi, yaşlıların önü kesilerek herhangi bir yetki sahibi olunmamasına rağmen yaş sorgulaması yapılması, yaşlılara maske takmaya ve başından aşağı kolonya dökmeye çalışılması, yine yetkili olmamasına rağmen yetkiliymiş gibi cezai işlem uygulamakla tehdit edilmesi, yaşlıların davranışlarını videoya alıp sosyal medyada mizah malzemesi yapılması gibi davranışların gazete haberlerine konu olduğu analiz edilmiştir.

Gazete haberlerinin içerik analizi sonucunda Yaşlılara karşı tutum kategorisinin ikinci kodu "damgalama" olarak belirlenmiştir. Buna göre yaşlıları potansiyel virüs yayıcı olarak görülmesiyle yaşlıların kalabalık yerde oturmasının virüsün yayılmasını artıracağının düşünülmektedir. Daha sonra yaşlıların başından aşağı kolonya dökülmesi sanki onların virüsten temizlenmesi gereken grup gibi algılamaktadır. Son olarak bir kişinin "Benden uzak dur. Sende korona var" diyerek yaşlı insanı virüslü olarak alenen damgaladı ̆̆ı görülmektedir.

Genç ve aktif nüfus tarafindan hayatın merkezine konan neoliberal kapital dünyada bakım ihtiyaçlarından dolayı yaşlılığın bir sorunsal olarak gündeme gelmesi ve onların toplumsal hayattan izole edilmeye çalışılması COVID-19 pandemisinden önce başlamıştır. Yaşlıları değersizleştiren onların dışlanmasını ve görünmez olmasına neden olan yaş ayrımcılı̆̆ kuşaklar arası bağları da zayıflatmaktadır (Danış \& Adanalı, 2019: 6). Dolayısıyla benzer bir durumdan kaynaklı yaşlılara karş1 tutum kategorisinin üçüncü kodu "dışlama" olarak saptanmıştır. Belediyelerin yaşlıların kullandığı bankları sökmesi, yaşlıların nedeni bilinmeden otobüslere alınmaması bu saptamanın örneklerindendir. Bu konuda bir yaşlı kendisine neden dişarda olduğunu soranlara "Ben hastaneye geldim, otobüse binip eve gideceğim ama otobüs beni almadı" cevabını vermiştir.

Bu kategorideki dördüncü kod ise "suçlama" olarak görünmektedir. Yaşl1lar için parklara akın ettikleri ve verdikleri cevapların bıkkınlık getirdiği ifadeleri, yaşlıların salgını ciddiye almadıkları yönündeki iddialar, yasağa uymadıklarının sıkça belirtilmesi, yaşlıların kendilerini sokağa attıklarının söylenmesi, bilinçsizlikle itham edilmesi, yapılan analizler neticesinde toplumun yaşlıları suçlar bir tavır içerisine girdiğini göstermektedir. Yaşlılara karșı tutum kategorisinin son kodu "azarlamadır". Buna göre bazı kişiler takındıkları tutumda ileri giderek yaşl1ları azarlamıştır. Örneğin haber14'de yaşlı birine, bir kişinin "Otur yerine, sen kimsin lan? Yaşından başından utan, devletin memuruna.. Feryat ettirmeyeceksin. Bana bağıramazsın. Yaşlı maşlı yok...." diye bağırdığı haberleştirilmiştir.

Bir damganın "görünürlüğ̈̈" ve "bilinirliği” birbirinden farklı olmasına rağmen ilintili olan iki kavramdır. Çünkü bir kişinin damgası çok görünüyorsa onun başkaları ile basit bir teması bile damgasının bilinir hâle gelmesine neden olacaktır. Ancak sadece bir kişinin damgasının bilinir 
olması sadece görünür olması ile alakalı değildir. Ayrıca kişiler hakkında daha önce kurulan dedikodusal temaslarda onun bilinir olmasını sağlayacaktır (Goffman, 2014: 88). Bu anlamda dışarı çıkıp görünür olan ve daha önce onların yaşlı olduğu bilgisi yaşlıları insanlar tarafindan damgalı hale getirmesini kolaylaştırmıştır. Nitekim yapılan içerik analiziyle görülmüştür ki toplumun bazı kesimleri alay ederek, dışlayarak, damgalayarak, suçlayarak ve azarlayarak damgalama davranışı göstermiştir.

Buradaki dikkat çeken bir diğer konu da damga eyleminde bulunan kişilerin nezaketi, nezaketin yitimi ve kendini aşağılama meseleleridir (Goffman, 2014: 114). Bu nokta da bir başka tartışma da kültürümüzde "başımızın tacl" olan yaşlılar hakkındaki değişen alg1 ve tutum değişikliğidir. $\mathrm{Bu}$ değişikliğin temel sebebi Türk toplumu özelinde değerlendirildiğinde modernleşmenin sonuçlarından biri olduğu görülmektedir. Modern anlayış ile birlikte yaşlıların geleneksel statü ve rollerini kaybetmekte, genellikle dişlanmakta ve yalnızlaştırılmaktadır.

Sosyal değişmenin hızlı yaşandığı modern dünyada popüler kültür etkinliğini arttırmaktadır. Genç kalmak genç görünme söylemleri bu anlamda popüler kültürü beslemektedir. Özellikle sanayi devrimi ile beraber yeniden tanımlanan toplumsal hayatta gençlik hep övülürken yaşlılık itici ve sevimsiz olarak gösterilmeye başlanmıştır. Yaşlıların toplumsal hayatın dışına atılması olarak nitelendirilebilecek bu süreç temel değerlerin hayatımızdaki önemini kaybetmesi ile bağlantılıdır (İnce, 2012: 28-29).

\subsection{Yaşlıların Verdiği Cevaplar}

Damgalı bireye hem herkes gibi olduğu hem de herkes gibi olmadığ 1 söylenmektedir. Damgalı bireyin "ne kadar herkes gibi olduğu, ne kadar olmadı̆̆ " meselesi bir tartışma konusudur. Bu çelişki damgalı kişinin kaderidir ve damgalıları temsil edenlerin sürekli olarak başa çıkmaları gereken bir güçlüktür (Goffman, 2014: 175). Bu noktada damgalanan yaşlilar yaşanan süreçte kendilerine yöneltilen tutuma karşıllk olarak bu durumla başa çıkmak için çeşitli yollara başvurmuştur. Bunlar harita5 ve tablo4'te görüldüğü gibi bazen fiziksel tepki, bazen dikkate almama, bazen üzüntü, bazen korku, suçlanma, inkâr olarak ortaya çıkmıştır.

Sosyal ve fiziki çevrelerinde söz sahibi olan, olayların gelişmesini kontrol edebilen/kontrol edebileceğine inanan ve olaylara yön verebileceğini düşünen yaşlılar daha mutlu olmaktadır. Bilgi ve birikimlerinin zirveye ulaştığ 1 yaşl1lık dönemini mutlu ve huzurlu geçirmek isteyecek yaşlıların, bu dönemi gurur kırıklıkları ve saygısızlığa maruz kalarak, kontrol edebilme gücünü ellerinden almak onlara hayal kırıklığı yaşatacaktır. Geçmiş dönemlerde olduğu gibi, kontrolü hala ellerinde tuttuğunu gören yaşlılar, olaylara ve yaşamlarına daha pozitif bakarak, kendilerini daha mutlu hissedecektir. Yaşamın mutlu bir şekilde sürdürülmesi, hayattan alınan zevkin artırılması, sağlıklı beslenme ve sağlıklı bir yaşamla iç içedir (İmamoğlu,2015). COVID-19 örneğinde hayatları ile ilgili kontrol başkaları tarafindan alınan yaşlıların tepkileri gazete haberlerinde yerini almıştır. Hemen belirtilmesi gerekir ki; yaşlıların dışarı çıkmaları yasağa aykırı eylemde bulunmaları onların haklı görüldüğü anlamına gelmemektedir. Buradaki problematik konu sebebi bilinmeden dışarıda görülen yaşlılara uygun olmayan davranışlarda bulunmasıdır. 
Harita 5: Yaşlıların Verdiği Cevaplar

\section{Yaşılıarın Verdiği Cevaplar, Kod-Alt kod-Bölümler Modeli}

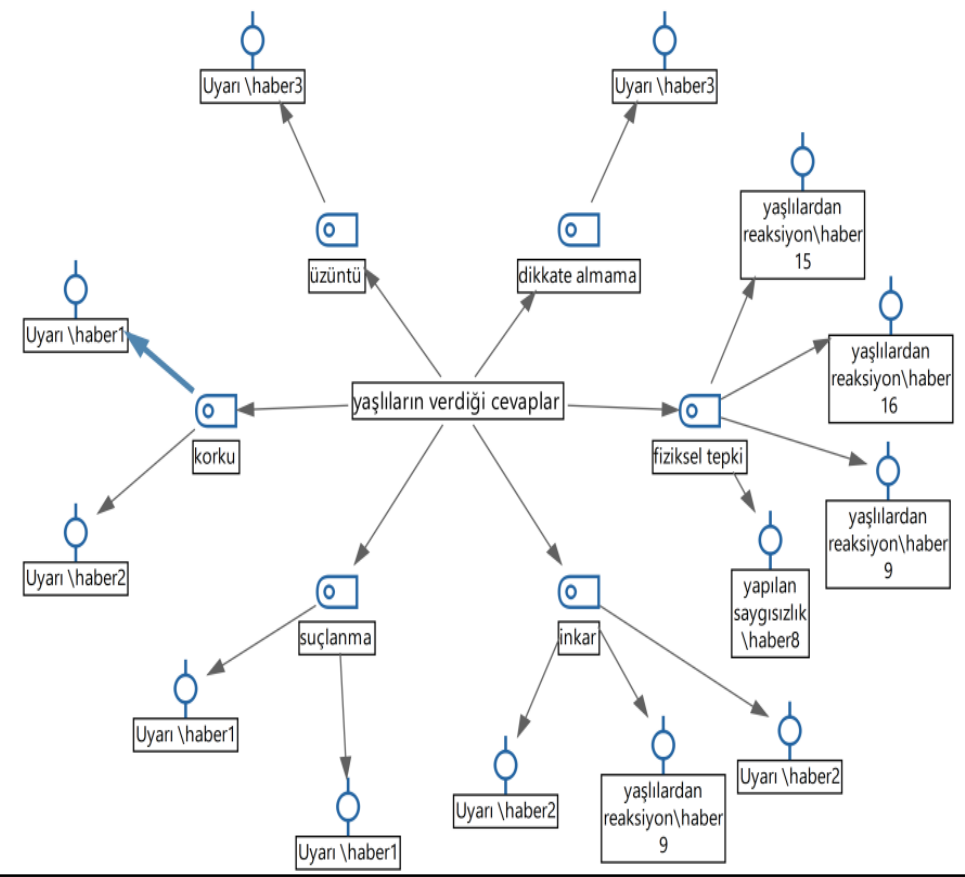

Yaşl1ların verdiği cevaplar kategorisi altında 6 kod oluşturulmuştur. Bunlar fiziksel tepki, dikkate almama, üzüntü, korku, suçlama ve inkârdır. Fiziksel tepki kodunda yapılan saygısızlık, yaşlılardan reaksiyon haberlerinden (haber8, haber9, haber15, haber16); Dikkate almama kodunda uyarı haberlerinden (haber3); üzüntü kodunda uyarı haberlerinden (haber3); korku kodunda uyarı haberlerinden (haber1, haber2); suçlanma kodunda uyarı haberlerinden (haber1); son olarak inkâr kodunda uyarı ve yaşlılardan reaksiyon haberlerinden faydalanılmıştır.

Tablo 4: Yaşlıların Verdiği Cevaplar Kategori, Kod, Alt Kod Tablosu

\begin{tabular}{|c|c|c|c|}
\hline $\begin{array}{l}\text { Belge } \\
\text { Grubu }\end{array}$ & $\begin{array}{l}\text { Belge } \\
\text { Adı }\end{array}$ & KategorilKod & Alt Kod \\
\hline $\begin{array}{l}\text { Yapılan } \\
\text { Saygısızlık }\end{array}$ & Haber8 & $\begin{array}{l}\text { Yaşlıların Verdiği } \\
\text { Cevaplar\Fiziksel } \\
\text { Tepki }\end{array}$ & $\begin{array}{l}\text { Zonguldak'ta yaşlı bir kadın, yeni tip koronavirüs (Kovid- } \\
\text { 19) tedbirleri kapsamında } 65 \text { yaşında olduğu gerekçesiyle } \\
\text { toplu taşıma aracına alınmadı. Bunun üzerine söz konusu } \\
\text { kadın, yolda minibüsün önüne yatarak hareket etmesini } \\
\text { engelledi. }\end{array}$ \\
\hline $\begin{array}{l}\text { Yaşlilardan } \\
\text { Reaksiyon }\end{array}$ & Haber15 & $\begin{array}{l}\text { Yaşlıların Verdiği } \\
\text { Cevaplar\Fiziksel } \\
\text { Tepki }\end{array}$ & $\begin{array}{l}\text { İzmir'de koronavirüs salgınına karşı sokakta dolaşan kişileri } \\
\text { uyaran Foça Belediye Gürbüz, } 65 \text { yaş üstü bir çifte de } \\
\text { esprili bir dille evlerine dönmesini gerektiğini söyledi. Çifte } \\
\text { uyarılarda bulunan Başkan Gürbüz, ismi Saadet olduğu } \\
\text { öğrenilen nineden baston yedi. }\end{array}$ \\
\hline $\begin{array}{l}\text { Yaşlilardan } \\
\text { Reaksiyon }\end{array}$ & Haber9 & $\begin{array}{l}\text { Yaşliların Verdiği } \\
\text { CevaplarlFiziksel } \\
\text { Tepki }\end{array}$ & $\begin{array}{l}\text { koronavirüs sebebiyle } 65 \text { yaş ve üstü vatandaşların sokağa } \\
\text { çıkma yasağına uymayan yaşlı bir vatandaş, askeri kamuflaj } \\
\text { kıyafeti giyerek bacaklarıyla bir ağaca baş aşağı asıldı. }\end{array}$ \\
\hline
\end{tabular}




\begin{tabular}{|c|c|c|c|}
\hline $\begin{array}{l}\text { Yaşlilardan } \\
\text { Reaksiyon }\end{array}$ & Haber16 & $\begin{array}{l}\text { Yaşliların Verdiği } \\
\text { Cevaplar|Fiziksel } \\
\text { Tepki }\end{array}$ & $\begin{array}{l}\text { Olay, Çankaya ilçesi Kurtuluş Parkı mevkiinde meydana } \\
\text { geldi. Polis ekipleri, koronavirüs tedbirleri kapsamında } \\
\text { sokağa çımaları yasaklanan } 65 \text { yaş ve üstü kişilere yönelik } \\
\text { denetim yaptı. Polisler, kimlik kontrolünde } 65 \text { yaşının } \\
\text { üzerinde olduğu belirlenen bir kişiyi, evine gitmesi } \\
\text { konusunda uyardı. Ancak ismi açıklanmayan vatandaş, eve } \\
\text { gitmeyeceğini söyledi. Polisin eve götürmek istediği } \\
\text { vatandaş, yola uzanarak buna da karşı çıtı. Kaldırımın } \\
\text { kenarında yola uzanan vatandaş, uzun uğraşlar sonucu polis } \\
\text { tarafından ikna edilerek evine götürüldü. }\end{array}$ \\
\hline Uyarı & Haber3 & $\begin{array}{l}\text { Yaşlıların Verdiği } \\
\text { Cevaplar|Dikkate } \\
\text { Almama }\end{array}$ & $\begin{array}{l}\text { Sokağa Çıkma Yasağının uygulanmasının ardından İstanbul } \\
\text { Kasımpaşa'da yaşlıar yasağa uymadı. Cami avluları ve ara } \\
\text { sokakların dolup taştı̆̆ semtte } 84 \text { yaşındaki yaşlı bir adam } \\
\text { ise akülü aracıyla tur attı. }\end{array}$ \\
\hline Uyar1 & Haber2 & $\begin{array}{l}\text { Yaşlıların Verdiği } \\
\text { Cevaplarlİnkâr }\end{array}$ & $\begin{array}{l}74 \text { yaşındaki bir vatandaş "o kadar büyük değilim" diyerek } \\
\text { polisi ikna etmeye çalış̧. }\end{array}$ \\
\hline Uyar1 & Haber2 & $\begin{array}{l}\text { Yaşlıların Verdiği } \\
\text { Cevaplar|İnkâr }\end{array}$ & $\begin{array}{l}\text { Uyarı esnasında yaşlı adamın "o kadar büyük değilim" } \\
\text { diyerek polisi ikna etmeye çalış }\end{array}$ \\
\hline Yaşlılardan & Haber9 & Yaşlıların. & "Her şey vatan için", "Her Türk asker doğar", "Ne mutlu \\
\hline Reaksiyon & & Cevaplar|İnkâr & $\begin{array}{l}\text { Türküm diyene" diye bağıran yaşlı adamla sohbet eden } \\
\text { vatandaş, "Hacı, her şey güzel de koronavirüs diye bir şey } \\
\text { var" diye tepki gösterdi. Yaşlı adama kaç yaşında olduğunu } \\
\text { soran vatandaş "16" cevabını aldı. }\end{array}$ \\
\hline Uyarı & Haber3 & $\begin{array}{l}\text { Yaşlıların Verdiği } \\
\text { CevaplarlÜzüntü }\end{array}$ & $\begin{array}{l}\text { Hiçbir şey söylemeyeceğim, devlet ne yaparsa haklıdır. } 84 \\
\text { yaşındayım, karşı sokakta oturuyorum. Bir şeyler aldım da, } \\
\text { korkmaktan cana bir şey olmaz ama tabi ki endişeliyiz. Dua } \\
\text { ediyorum başka bir şey yok }\end{array}$ \\
\hline Uyarı & Haber1 & $\begin{array}{l}\text { Yaşlıların Verdiği } \\
\text { CevaplarlKorku }\end{array}$ & $\begin{array}{l}\text { Korona virüs konusu başladı başlayalı hayatta çıkmıyorum. } \\
\text { Bir saat dışarıda oturmuş değilim. Ben şimdi buraya çıktım } \\
\text { deyip burada kalmayacağım. Ben oturdum siz geldiniz, } \\
\text { devlet ne dediyse onu yapmamız lazım }\end{array}$ \\
\hline Uyarı & Haber2 & $\begin{array}{l}\text { Yaşlıların Verdiği } \\
\text { Cevaplar|Korku }\end{array}$ & $\begin{array}{l}\text { Kimlik kontrolü esnasında ise yaşlı bir vatandaş, kendisine } \\
\text { "dur" ihtarında bulunan polisten motosikletine binerek kaçtı. }\end{array}$ \\
\hline Uyarı & Haber1 & $\begin{array}{l}\text { Yaşlıların Verdiği } \\
\text { Cevaplar|Suçlanma }\end{array}$ & $\begin{array}{l}\text { Ekmek almaya çıktım, geldim oturdum hemen gidiyorum } \\
\text { karşıdan firından ekmeği alıp eve gideceğim. }\end{array}$ \\
\hline Uyarı & Haber1 & $\begin{array}{l}\text { Yaşlıların Verdiği } \\
\text { CevaplarlSuçlanma }\end{array}$ & $\begin{array}{l}\text { Aslında sokağa çıkmamak güzel bir şey, Sağlık } \\
\text { Bakanlığımız tedbirleri alıyor. Ben yeni çıktım kimse yoktu } \\
\text { dedim bir hava alayım sonra eve çıkacağım zaten. } 65-70 \text { yaş } \\
\text { üzerine etki yapar. }\end{array}$ \\
\hline
\end{tabular}

COVID-19 ile beraber getirilen yaşlıların sokağa çıkma yasağına yönelik yaşlılara karşı geliştirilen gazete haberlerine yansıyan tutuma yaşlıların verdiği cevap kategorisinin ilk kodu "fiziksel tepki" olmaktadır. Yaşlıların kendilerine karşı geliştirilen tavra kimi zaman fiziksel tepkilerle cevap verdikleri görülmektedir. Örneğin toplu taşımaya alınmayan bazı yaşlılar arabanın önüne yatarak, kendilerine istemedikleri şekilde uyarıda bulunanlara bastonlarını göstererek, ya da akrobatik hareketler yaparak karşılık vermişlerdir.

İkinci kod ise "dikkate almama"dır. Buna göre bazı yaşlılar kendilerine yöneltilen davranışları umursamama eğilimi göstermiştir. Goffman bu konuda bazı damgalanmış bireylerin damgalayana karşı şefkatli yaklaşımından bahsetmektedir. Ona göre damgalama eyleminde bulunan herkes kötü niyetli değildir. Kötü niyetli olduklarında ise bu onların eksik ve yanlış bilgilerinden kaynaklanmaktadır. İmalı bakışlara, kötü sözlere ve kaba davranışlara benzer

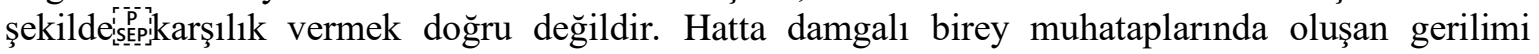
azaltmak için bilinçli bir çaba göstermelidir. Ya onları görmezden gelmeli ya da anlayışlı olarak eğitme yoluna gitmelidir (Goffman, 2014: 165-166). 
Damgalanmış kişinin, zaman becerebileceği bir konumda bulunabileceğini fark edilmektedir (Goffman, 2014: 115). Bu motivasyonla yaşlıların verdiği cevaplar kategorisinin üçüncü kodu "inkar" olmaktadır. Yaşlılar genellikle yasağı kapsayan yaş diliminde olmalarına rağmen "o kadar büyük değilim" cevabı vermişlerdir. Hatta yaşlı birine kaç yaşında olduğunu soran vatandaş " 16 " cevabını aldığı görülmüştür.

Goffman'a göre bütünüyle ve görünür bir şekilde damgalanmış bireyler kendilerine özgü bir aşağılanmanın 1zdırabını çekmektedir (Goffman, 2014: 180). Goffman'ın tespitiyle benzer şekilde dördüncü kod ise “üzüntü” dür. Buna göre yaşl1lardan bazıları üzüntülü ve endişeli olduklarını dile getirdiği görülmektedir.

Gazete haberlerinin içerik analizi sonucunda yaşlıların verdiği cevaplar kategorisinin beşinci kodu "korku" olarak belirlenmiştir. Yaşl1lar kendilerine yönelitilen davranışlara karşıllı mevcut erk den korktuklarını dile getirmektedir. Örneğin bir yaşlı "Ben yeni oturdum siz geldiniz, devlet ne dediyse onu yapmamız lazım" şeklinde reaksiyon vermiştir. Ayrıca gazete haberlerinde bazı yaşlıların kimlik kontrolü esnasında kendisine dur ihtarı verilmesine rağmen korkarak kaçtığı görülmektedir. Bu kategorinin son kodu ise "suçlanma" duygusudur. Bazı yaşlılar kendilerine hesap soranlara suçlu hisseder bir şekilde hemen geri döneceğini, ya da yaptığının yanlış olduğunu belirten ifadeler kullanmışlardır.

Yaşl1lar kendilerine karşı geliştirilen tutum karşısında etkiye tepki vermişlerdir. Bu konuda Yaşlıların maddi ihtiyaçlarının yanında manevi ihtiyaçlarının da olduğu unutulmamalıdır. Öyle ki yaşl11ık döneminde bazen manevi ihtiyaçlar maddi ihtiyaçların önüne geçmektedir. Sevgi, saygı ve ilgi yaşlılar için manevi değerlerdir. Yaşlıların toplumdan soyutlanması, işe yaramazlık duygusuna kapılmaları ya da onlara gerekli manevi değerleri göstermemek önemli bir sorunsaldır. Toplum sevgi, saygı değerlerinin yaşlılar için ne ifade ettiğini iyi kavrayabilmelidir (İnce, 2012: 37). Aksi halde içerik analizi kodlarından da görüleceği üzere onlara karşı geliştirilen yanlış tutumun onlardaki karşılı̆̆ korku, suçlanma, üzüntü vb. olacaktır. Bir gruba bu duyguları hissettirmek insani değerlerle örtüşmeyecektir.

Yaşl11ıkta rol ve statü kaybı sadece yaşl11ıkla alakalı değildir. Yaşl11ık döneminin nasıl geçirildiği ile de ilgilidir. Örneğin, yaşlı bireyin, biyolojik- fiziksel durumuna, görünüşüne, sağlık durumuna zihinsel melekelerine, kendine bakımına göre etkinlik düzeyi değişmektedir. Bunların yanında yaşlanma etkinliğini belirleyen yaşama koşullarına bir anlamda sosyo- ekonomik durumuna, ekonomik, sosyal ve kültürel sermayesine göre değişmektedir. Bir anlamda bu süreç kaliteli yaşlanma çerçevesinde değerlendirilmektedir (Gitmez, 2000: 95; Görgün-Baran, 2008). Bununla doğru orantılı olarak yapılan gazete içerik analizlerinde bazı yaşlıların karşılaştıkları davranışlara fiziksel tepki verebilecek fiziksel donanıma sahip ya da dikkate almayacak kadar psikolojik yeterliliği olduğu görülmektedir. Bazı yaşlıların ise daha duygusal tepkiler vererek bahsedilen farklılığı gözler önüne sermektedir.

\subsection{Davranışlara Tepkiler}

COVID-19 döneminde yaşl1lara karşı geliştirilen davranışlara karşıllk tepki geliştirenlerde bulunmaktadır. Bu tepkiler incelenen gazete haberlerinden yapılan analizlerde (harita6 ve tablo5) görülmektedir. Esasında normal kişiler pek çok durumda, damgalı kişiye karşı, sanki kusurunun pek de önemi yokmuş gibi davranma nezaketini gösterebilirler (Goffman, 2014: 169-170). Bu durumu Goffman şöyle açıklamaktadır: "Şüphesiz ki, damgalı bireyin kaderini paylaşmak zorunda olmayan ya da buna ilişkin bir dikkat ve özen göstermek için çok zaman harcamak durumunda kalmayan ve tam da bu sebeple șepsöz konusu kişi ile sürekli temasta bulunmak zorunda olanlara nazaran onu daha kolay kabullenebilen kişiler de mevcuttur" (Goffman, 2014: 93).

Emre Kongar yaşlılık döneminin bir arınma süreci olduğundan bahsetmektedir. Bu süreç insanın rasyoneliteden çıktığı bir süreçtir. Yıllar içinde insanların yaşadığı deneyimler maddi 
anlamdaki zevklerin öneminin olmadığını göstermektedir. Bu durum yaşlılık döneminin insanı bilgeliğe ulaştırdığ1 bir dönem olduğunu göstermektedir (Kongar, 2012). Bu durumun bilincinde olarak yaşlılara saygı gösterilmelidir. Ayrıca bir gün aynı dönemi geçireceğini bilerek ve empati kurarak yaşlılara tavır geliştirmelidir. Bu konuda yanlış bir tavır görüldüğünde de tepkileri dile getirmek bir insanlık görevi olduğunu unutmamak gerekmektedir.

Harita 6: Davranışlara Tepkiler

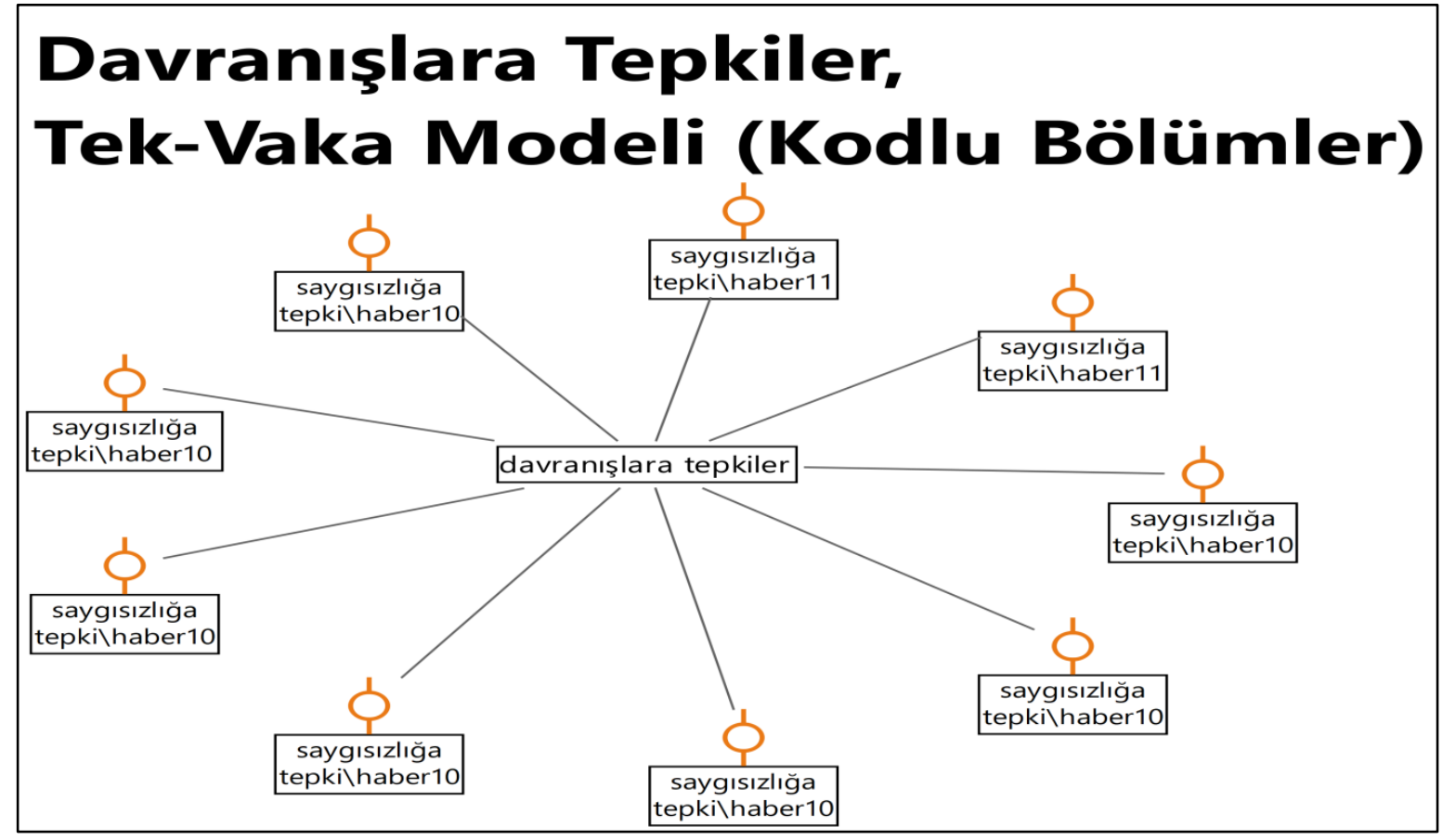

Davranışlara tepkiler kategorisinin altında bir kod oluşturulmamıştır. Saygısızlığa tepki haberlerinin (haber10, haber11) altında doğrudan haber içeriklerinden oluşan alt kodlar verilmiştir.

Tablo 5: Davranışlara Tepkiler Kod, Alt Kod Tablosu

\begin{tabular}{|c|c|c|c|}
\hline $\begin{array}{l}\text { Belge } \\
\text { Grubu }\end{array}$ & Belge Adı & Kod & Alt Kod \\
\hline $\begin{array}{l}\text { Saygisızlığa } \\
\text { Tepki }\end{array}$ & Haber10 & $\begin{array}{l}\text { Davranışlara } \\
\text { Tepkiler }\end{array}$ & $\begin{array}{l}\text { İçişleri Bakanı Süleyman Soylu, Twitter hesabından bir } \\
\text { açıklama yaptı. Soylu, Twitter hesabından yaptığı } \\
\text { paylaşımda,"65 yaş ve üstü risk grubunda olan } \\
\text { büyüklerimiz evde kalarak sadece koronavirüsten değil, } \\
\text { elinde telefonla dolaşı onları kaydeden etkileşim } \\
\text { hastalarından da korunacaklardır" ifadelerine yer verdi. }\end{array}$ \\
\hline $\begin{array}{l}\text { Saygısızlı̆ga } \\
\text { Tepki }\end{array}$ & Haber10 & $\begin{array}{l}\text { Davranışlara } \\
\text { Tepkiler }\end{array}$ & $\begin{array}{l}\text { Yazık gerçekten ne desem bilemiyorum. Adam güzel güzel } \\
\text { açılıyor durmadan lafinı kesmesine mi polisim diye } \\
\text { kandırılmasına mı otobüs beni almadı derken ki } \\
\text { mahcubiyetine mi üzülsem bilemiyorum. Bu da bir suç ve } \\
\text { cezasız kalmamalı. \#videoyukaldır }\end{array}$ \\
\hline $\begin{array}{l}\text { Saygısızlığa } \\
\text { Tepki }\end{array}$ & Haber10 & $\begin{array}{l}\text { Davranışlara } \\
\text { Tepkiler }\end{array}$ & $\begin{array}{l}\text { \#videoyukaldır video izlerken gözlerim doldu gerçekten ve } \\
\text { bununla dalga geçilmesi devlet zaten gerekli önemleri aldı } \\
\text { sana mı düştü yaşlılarımızı uyarmak. }\end{array}$ \\
\hline $\begin{array}{l}\text { Saygısızlığa } \\
\text { Tepki }\end{array}$ & Haber10 & $\begin{array}{l}\text { Davranışlara } \\
\text { Tepkiler }\end{array}$ & $\begin{array}{l}\text { Onuru ve haysiyeti olan kişiler yaşlılar üzerinden etkileşim } \\
\text { kasmaz ve o videoları silerler. O insanların aileleri, } \\
\text { torunları ve yakınları var! \#videoyukaldır }\end{array}$ \\
\hline
\end{tabular}




\begin{tabular}{|c|c|c|c|}
\hline $\begin{array}{l}\text { Saygisızlığa } \\
\text { Tepki }\end{array}$ & Haber10 & $\begin{array}{l}\text { Davranışlara } \\
\text { Tepkiler }\end{array}$ & $\begin{array}{l}\text { Yaşını beşe katlayan adamın sesini titreterek mizah } \\
\text { çıkaracağını zannedecek kadar zavallısın, küstahça soruna } \\
\text { eğilip bükülerek cevap veren adamı dinlemeye dahi } \\
\text { tenezzül etmeyecek kadar nezaketten bihabersin. Sen } \\
\text { toplumlar için en öldürücü virüsten daha tehlikelisin }\end{array}$ \\
\hline \multirow[t]{2}{*}{$\begin{array}{l}\text { Saygısızlığa } \\
\text { Tepki }\end{array}$} & Haber10 & $\begin{array}{l}\text { Davranışlara } \\
\text { Tepkiler }\end{array}$ & $\begin{array}{l}\text { Yüzündeki o ifadeden dolayı gözüme gram uyku girmiyor. } \\
\text { \#videoyukaldır }\end{array}$ \\
\hline & & & $\begin{array}{l}\text { Sevgili genç kardeşlerim lütfen büyüklerimize karşı } \\
\text { saygımızı kaybetmeyelim, onları incitmemeye gayret } \\
\text { edelim. Eğer siz de paylaştıysanız, lütfen o söz konusu } \\
\text { \#videoyukaldır'ın. }\end{array}$ \\
\hline $\begin{array}{l}\text { Saygısızlığa } \\
\text { Tepki }\end{array}$ & Haber10 & $\begin{array}{l}\text { Davranışlara } \\
\text { Tepkiler }\end{array}$ & $\begin{array}{l}\text { Büyüklerimize yönelik yapılan onur kırıcı bütün videoları } \\
\text { kaldırın. Lütfen \#videoyukaldır }\end{array}$ \\
\hline $\begin{array}{l}\text { Saygısızlığa } \\
\text { Tepki }\end{array}$ & Haber11 & $\begin{array}{l}\text { Davranışlara } \\
\text { Tepkiler }\end{array}$ & $\begin{array}{l}\text { Tepkiler üzerine İçişleri Bakanlığı harekete geçti. } \\
\text { Bakanlık'tan yapılan açıklamada "Dün hepimizi üzen } \\
\text { görüntülere neden olan M.T.E., Ankara İ Emniyet } \\
\text { Müdürlüğü ekiplerince yakalanıp hakkında işlem } \\
\text { başlatıldı. Videoya çektiği İhsan amcamızı, } \\
\text { kaymakamımız ziyaret ederek, bakanımız Süleyman Soylu } \\
\text { ile telefonda görüştürdü. Amcamızdan bu münasebetsizlik } \\
\text { adına özür diledik." ifadelerine yer verildi. }\end{array}$ \\
\hline $\begin{array}{l}\text { Sayg1sızlığa } \\
\text { Tepki }\end{array}$ & Haber11 & $\begin{array}{l}\text { Davranışlara } \\
\text { Tepkiler }\end{array}$ & $\begin{array}{l}\text { Adalet Bakanı Abdülhamit Gül, "Adalet sistemimiz, evde } \\
\text { kalmanın yalnız İhsan Amca'ya mahsus olmadığını } \\
\text { anlaması için şüphelinin } 15 \text { gün konutundan çıkmamasına } \\
\text { ve salgın riskinden sonra da büyüklerimizin kıymetini } \\
\text { anlaması için huzurevi ziyareti yapmasına karar verdi" } \\
\text { dedi. }\end{array}$ \\
\hline
\end{tabular}

Davranışlara tepkiler kategorisinin altında bir kod oluşturulmamıştır. Saygısızlığa tepki haberlerinin altında doğrudan haber içeriklerinden oluşan alt kodlar verilmiştir. Yaşlılara karşı geliştirilen tutum bazı kişiler tarafından tepki ile karşılanmıştır. Özellikle iç işleri bakanının ,"65 yaş ve üstü risk grubunda olan büyüklerimiz evde kalarak sadece koronavirüsten değil, elinde telefonla dolaşıp onları kaydeden etkileşim hastalarından da korunacaklardır" söylemi haberleştirilmiş ve yaşlılara yapılan yanlış hareketlere dikkat çekmiştir. Ayrıca gazete haberlerinde bazı sanatçıların bu duruma "Büyüklerimize yönelik yapılan onur kırıcı bütün videoları kaldırın, "Yaşını beşe katlayan adamın sesini titreterek mizah çıkaracağını zannedecek kadar zavallısın, küstahca soruna eğilip bükülerek cevap veren adamı dinlemeye dahi tenezzül etmeyecek kadar nezaketten bihabersin. Sen toplumlar için en öldürücü virüsten daha tehlikelisin", "Sevgili genç kardeşlerim lütfen büyüklerimize karşı saygımızı kaybetmeyelim, onları incitmemeye gayret edelim. "tepkilerini dile getirdikleri görülmektedir.

Toplumsal değişme ile beraber yaşlının yaşadığı değer ve statü kaybı elbette ki onları olumsuz anlamda etkilemektedir. Yaşadığımız dönemde aktif-çalışma-üretme çağını geride bırakan, yaşlanarak çeşitli bedensen ve fiziksel kayıplar ile birlikte sosyal statü ve değer kaybına uğrayan yaşlılar kendilerini daha işlevsiz ve gereksiz görme eğilimindedir. Böylece yaşlılar kendilerini yalnız hissetmesi ile sonuçlanan bu süreç, toplumda sosyo-kültürel boşlukların oluşmasına sebep olacaktır (Kolland,1994:338'den aktaran Gitmez, 2000: 79). Bu sebeple devlet büyükleri, toplumda önde görünen kişiler başta olmak üzere herkesin bu konuda duyarlı olması beklenmektedir. Keza yapılan bu çalışmada yapılan gazete içerik analizinde de, yaşlılara karşı yapılan saygısız davranışlara duyarlı kesimi hiç zaman kaybetmeden tepki gösterdiği görülmektedir: "Adalet Bakanı Abdülhamit Gül, "Adalet sistemimiz, evde kalmanın yalnız Ihsan Amca'ya mahsus olmadığını anlaması için şüphelinin 15 gün konutundan çıkmamasına ve salgın riskinden sonra da büyüklerimizin klymetini anlaması için huzurevi ziyareti yapmasına karar verdi" dedi." 


\section{Sonuç}

Dünya nezdinde gündem olan konulardan biri de yaşl1lık olgusudur. Nüfusumuzun hızla artmasından dolayı bu olgu ülkemiz içinde oldukça önemli hale gelmektedir. Sanayileşme ve beraber gelen kentleşme, göç vb. konular başta olmak üzere birçok modern dünya konuları yaşlıları etkilemektedir. Ayrıca daha önceki döneminde aktif olan yaşlının emeklilikle beraber bu aktifliğini kaybetmesi, gelirinin azalması, başkalarının bakımına ihtiyaç duyması, statü kayıpları gibi konular ile beraber yaşlı bireyler sosyal olarak yalıtım, yalnızlık, değersizlik duyguları geliştirebilmektedir. $\mathrm{Bu}$ durumda yaşlılık çoğunlukla olumsuz olarak algılanmakta ve geçmişe özlem duyulmaktadır (Köroğlu \&Köroğlu, 2020: 820).

Yaşlılık olgusunun ne olduğu ne zaman başladığı, kime yaşlı denildiği tartışılmaktadır. Yaşl1lığın en kabul gören tanımı ise Dünya Sağlık Örgütü tarafından yaşa bakılarak yapılmaktadır. Son 50 yıldaki Türkiye nüfusundaki değişimi incelediğimizde, toplam nüfusun 3 kat artışına nazaran yaşlı nüfusun neredeyse 10 kat artış göstermektedir. Bugün Türkiye, dünyanın en hızlı yaşlanan ülkelerindendir. Bu hız konunun ciddiyetini göstermektedir. Dolayısıyla acilen yeterli sosyal politika geliştirmek gerekmektedir. Aksi halde Türkiye'nin genç bir nüfusu olduğunu düşünüp bunun hep böyle kalacağına inananlar, yaşlanma olgusunu uzak gelecekteki bir durum olarak değerlendirecek ve dolayısıyla bir anlamda Peter Pan Sendromu yaşanmış olacaktır. Hikâyeye göre, Neverland'de yaşayan Peter Pan karakteri, hiç yaşlanmayacak bir çocuktur. Peter Pan, diğer çocukları da hiç yaşlanmama vaadiyle Neverland'e davet eder. Peter Pan Sendromundan mustarip olan kişi uzun yaşamak ister, ama yaşlanmak istemez, yaşlanacağına inanmaz. Oysa Toplumun yaşlanması durdurulamaz ya da tersine çevrilemez bir durumdur. Üstelik Türkiye'nin çocukları zannedildiğinden çok daha büyük bir hızla yaşlanmaktadır. (Arun, 2019: 54-56).

Yaşlı1ık, yaşlanma ve yaşlılar konusu ile ilgilenme çok eski zamanlardan beri vardır. İnsanın kendini inceleme nesnesi olarak ele aldığı zamanlar bu ilginin başlangıcı kabul edilebilir. Ancak bilimsel anlamda yaşlılık çalışmalarının son yüzyılla birlikte başladığı kabul edilmektedir (İnce, 2012: 8). Örneğin Antik Roma'da Cicero yaşl1l1k döneminin "bahtsız bir çă̆g" olarak görülmesini eleştirmektedir. Böyle görülmesinin altında; faal çalışma hayatından uzak kalma, bedenin güçsüzleşmesi, zevklerden yoksun kalma, ölümün bir adım ötede bekleyişi. Gibi nedenlerin olduğunu söylemektedir (Cicero, 2018: 35). Görüldüğ̈̈ üzere yaşl1lığın olumsuzlanmasının kınanan bir durum olması çok eski devirlere dayanmaktadır. Çünkü Geleneksel toplumların birçoğunda yaşlılara toplumun en önemli üyeleri gözüyle bakılmaktadır. Yaşlılara atfedilen inanç ve değerlerden dolayı toplumsal ayrıcalıklar onlara yöneliktir. Yaşlılık eskimeyi çağrıştıracak bir olgu olarak değerlendirmek yerine deneyimlerinden faydalanılması gereken, saygı gösterilen bilge kişi olarak görülmektedir. Bunun en bariz örneklerinden biri ahilik teşkilatıdır. Bu teşkilatın yapılanmasında usta konumunda bulunan yaşı büyük birey sosyal statü olarak toplumda çok iyi bir konumda bulunmaktadır. Bu teşkilatlanmanın dönemin yaşlılık değerine yüklediği anlamı pekiştirdiğini söylemek yanlış olmayacaktır (Dağdelen, 2017: 289). Yaşl11ıkla ilgili olumlu algıların şekillenmesinde İslam dininin yaşlılara verdiği değerin de önemli bir yeri bulunmaktadır. İslam dini, Türklerdeki atalar kültü anlayışını geliştirmiş ve yaşlılara saygının dinin bir gereği olarak kabul görmesini sağlamıştır (Çetin, 2020: 239). Sonuç olarak Geleneksel toplumlarda bir değer olarak yaşlılığın gündelik hayatta oldukça kıymetli bir yere sahip olduğunu söylemek yanlış olmayacaktır. Fakat Sanayi Devrimi sonrası yaşanan modern dünyada yaşl11ık algılayışının değiştiği görülmektedir. Geleneksel toplumlarda yaşlılığın statü değeri yüksek iken sanayileşme düşük, sanayileşme sonrası toplumlarda ise sanayileşme yüksek iken yaşlıların statü değerleri düşüktür (Dağdelen, 2017: 289).

Yaşlılıkla ilgili algının değişime uğraması son zamanlarda COVID-19 pandemisiyle gün yüzüne çıkmıştır. Çünkü COVİD-19 tüm yaş gruplarındaki insanlara enfekte olmakla beraber bulaşma ve yayılma hızı ayrıca mortalitesi değerlendirildiğinde yaşlı nüfusa daha fazla etki ettiğinden dolayı onlara yönelik çeşitli kısıtlamalara gidilmiştir (Ovalı, 2020: 24). Kısıtlamaların 
başında sokağa çıkma yasağı gelmektedir. Sokağa çıkma yasağı getirilen yaşlıların çeşitli davranışlara maruz kaldığı görülmüştür. $\mathrm{Bu}$ davranışlar yaşlılık algısındaki değişimi göstermektedir. $\mathrm{Bu}$ çalışmada bahsedilen algı değişimi 16 online gazete haberinin damgalama teorisi çerçevesinde içerik analizi yapılarak anlatılmaya çalışılmıştır. Öncelikle sınırlamanın getirilmesi ile birlikte yapılan online haberler toplanmıştır. Sonrasında gazete haberleri dört kategoride incelenmiştir. Bu kategoriler uyarı, yapılan saygısızlık, yaşlıların tepkisi ve saygısızlığa tepki haberleridir. Haberlerin içeriği ile ilgili ayrı bir kategorizasyona gidilmiştir. "Değişen Yaşlılık Algisı: COVID-19 Ile Damgalanan Yaşlılar" temel temas1 ile incelenen gazete haberlerinin içeriğinin yaşlıların dışarı çıkma nedenleri, yaşlılara karşı tutum, yaşlıların verdiği cevaplar ve davranışlara tepkiler konuları etrafında toplandığı görülmüştür.

Haber içeriklerinden yaşlıların genellikle mecburi sebeplerle, can sıkıntısından, ya da kısıtlamayı bilmemesinden dolayı dışarıya çıktığı anlaşılmıştır. Dışarı çıkan yaşlılara karşı geliştirilen tutumlar değişen yaşlılık algısını göstermiştir. Genel olarak dışarıda yaşlı bir birey ile karşılaşan kişiler onları azarlama, suçlama, dışlama, alay etme gibi damgalama eylemleri geliştirmiştir. Bu duruma cevap olarak yaşlılar ise fiziksel tepki, dikkate almama, üzüntü, korku, kendini suçlu hissetme, ya da yaşlarını inkâr etme ile karşılık vermiştir. Bu yaşananlara duyarlı kişilerin ve devlet yetkililerin tepki gösterdiği haber içeriği analizlerinden ortaya çıkmıştır. Sonuç olarak bu çalışmada COVID-19 pandemisi ile beraber yaşlıların bir damgalanmaya maruz kaldığını ve yaşlılara yönelik algının olumsuz anlamda değiştiği görülmektedir.

\section{Kaynakça}

Arun Ö. (2019). "Yaşlanmayı Aşmak". Mekânda Adalet ve Yaşlılık. (Edit.) Danış Didem, Adanalı Yaşar Adnan. Print Center Bask1. 54-61.

Baran A. G. (2008). Yaşlılıkta Sosyalizasyon Ve Yasam Kalitesi, Yaslı Sorunları Araştırma Dergisi, (2): 86-97.

Baran,A. G. (2004). Yaşlılık Sosyolojisi, Yaşlılık / Disiplinler Arası Yaklaşım, Sorunlar, Çözümler $\left(\dot{I}_{\mathcal{C}}\right)$, (Der.: V. Kalınkara), Odak İletişim Yay.

Bayrak F. (2018). Yaşlllık Olgusuna Sosyolojik Bir Yaklaşım [Yayımlanmamış Yüksek Lisans Tezi]. Firat Üniversitesi Sosyal Bilimler Enstitüsü.

Cicero, De S. (2018). Yaşlılık Üzerine. Çev.: Çiğdem Dürüşken, Alfa Basım Yayım.

Çetin, N. (2020).Türkiye'de Yaşl1lık Ve Yaşl1lıkla Yüzleşme Üzerine Bir Değerlendirme. Motif Akademi Halkbilimi Dergisi, 13(29), 236-242.

Dağdelen, M. (2017). Tüketim Kültürüne Alternatif Bir Bakış: Yaşl1lık Değerinin Tüketimi. Uluslararast Sosyal Araştırmalar Dergisi/The Journal Of International Social Research, 10(49), 283-294.

Danış D. \& Adanalı Y. A. (2019). Mekânda Adalet ve Yaşlılık, Print Center Baskı.

Gitmez, Ş. K. (2000). Yaşlıların Farklı Kentsel Koşullarda Yaşam Uyumları Ĕgilimleri, Tutum ve Davranışlarl, [Yayımlanmamış doktora tezi]. Ankara Üniversitesi Sosyal Bilimler Enstitüsü.

Goffman, E. (2014). Damga: Örselenmiş Kimliğin İdare Ediliş̧i Üzerine Notlar. (Çeviren Ş. GenişL. Unsald1-S.N. Ağırnaslı) Heretik Yayıncılık.

İçli, G. (2010). Yaşlıların ve Yaşlılığın Değerlendirilmesi Denizli İli Üzerine Niteliksel Bir Araştırma. Yaş̧l Sorunları Araştırma Dergisi, (1), 1-13. 
İçli, G. (2016). "Sosyal Statü Ve Rol Bağlamında Yaşl1lık”, Yaşl1lık Sosyolojisi. (Edit.) Harun Ceylan. Nobel Yayınc1lık, 41-55.

İmamoğlu, V. (2015). İleri Yaşlardaki Türklerin Yaşam Çevreleri Ve Daha İyi Bir Yaşam İçin Öneriler. Metu Jfa, 32(1),105-119.

İnce, A. (2012). Yaşlanma Döneminde Dini Hayat (Sakarya İli-Merkez İlçeler Örneği) [Yayımlanmamış doktora tezi].Ankara Üniversitesi Sosyal Bilimler Enstitüsü.

Kalaycıŏlu, S., Tol, U.U., Küçükural, Ö. \& Cengiz, K. (2003). Yaşlılar ve Yaşlı Yakınları Açısından Yaşam Biçimi Tercihleri. Türkiye Bilimler Akademisi Raporları 5.

Karcioğlu, Ö. (2020). What İs Coronaviruses, And How Can We Protect Ourselves? Ankara Tip Dergisi, 2(1), 66-71.

Kongar, E. (2012). Yaşamin Anlamı: Denemeler. Remzi Kitapevi. 135-143.

Köroğlu, C. Z. \& Köroğlu, M. A. (2015). Mekânın Dönüşümü Ve Yaşl1lık Üzerine: Kentleşme Ve Yaşl1lık Olgusu. Uluslararası Sosyal Araştırmalar Dergisi/The Journal Of International Social Research, 8(41),812- 821.

Kuckartz U. \& Rädiker, S. (2019). Analyzing Qualitative Data With Maxqda Text, Audio, And Video (E Book). Springer Fachmedien Wiesbaden Gmbh, Springer Nature.

Neuman W. L. (2014). Toplumsal Araştırma Yöntemleri, Nitel Ve Nicel Yaklaşımlar. Desen Ofset.

Ovalı F. (2020). Yeni doğanlarda Covıd-19 Enfeksiyonları. Anadolu Kliniği Tıp Bilimleri Dergisi, 25(1): 23-35.

Özkul M. \& Kalaycı I. (2015). Türkiye'de Yaşlılık Çalışmaları. Sosyoloji Konferansları, 52 (2) 259-290.

T.C. Sağlık Bakanlığı, Covid-19 Rehberi, Mart 2020. https://www.tahud.org.tr/file/4f42cbfd-bbd94bf4-91b0-29698f53f198/COVID-19_Rehberi.pdf Erişim Tarihi: 04/04/2020.

Yıldırım, A. \& Şimşek, H. (2006). Sosyal Bilimlerde Nitel Araştırma Yöntemleri. Seçkin Yayıncilik.

https://www.haberler.com/uyarilari-dikkat-almayan-yaslilar-aciklamalariyla-13037543-haberi/ (Erișim Tarihi:04.20.2020).

https://www.haberler.com/ozel-istanbul-da-yasaga-uymayan-yaslilar-ilginc-13042143haberi/(Erișim Tarihi:04.20.2020).

https://www.haberler.com/istanbul-da-65-yas-ustu-yaslilar-sokaga-cikma-13039712-haberi/(Erișim Tarihi:04.20.2020).

https://www.haberler.com/yaslilar-korona-virusune-aldiris-etmeyince-banklar-13029734haberi/(Erișim Tarihi:04.20.2020).

https://www.haberler.com/engelli-yasliya-hakaret-eden-genc-13049702-haberi/(Erișim Tarihi:04.20.2020).

https://www.haberler.com/yasli-vatandasa-saygisizlik-yaparak-tepki-13046797-haberi/(Erișim Tarihi:04.20.2020).

https://www.haberler.com/ozel-yaslilara-kimlik-sorup-65-yas-ustunu-13047385-haberi/(Erișim Tarihi:04.20.2020).

https://www.haberler.com/zonguldak-ta-halk-otobusune-alinmayan-yasliyi-13049045haberi/(Erișim Tarihi:04.20.2020). 
https://www.haberler.com/yasli-adam-yol-kenarindaki-agaca-bas-asagi-asilip-13047478haberi/(Erișim Tarihi:04.20.2020).

https://www.haberler.com/sosyal-medyada-utandiran-video-bakan-soylu-13046127-haberi/(Erișim Tarihi:04.20.2020).

https://www.haberler.com/son-dakika-yasi-vatandasin-korkutuldugu-13049120-haberi/(Erișim Tarihi:04.20.2020).

https://www.haberler.com/yasli-adamin-zabitadan-pogaca-da-istedigi-anlar-13047018haberi/(Erișim Tarihi:04.20.2020).

https://www.haberler.com/polisin-evine-birakmak-istedigi-yasli-adam-yayan-13047449haberi/(Erișim Tarihi:04.20.2020).

https://www.haberler.com/bir-polis-memuru-manisa-otogari-nda-yasli-adama-13055938haberi/(Erișim Tarihi:04.20.2020).

https://www.haberler.com/video/evinize-gidin-diyen-baskan-nineden-bastonu-yedi13044884(Erișim Tarihi:04.20.2020).

https://www.haberler.com/ankara-da-yasagi-ihlal-eden-vatandas-eve-gitmemek-13045279haberi/(Erișim Tarihi:04.20.2020). 